Review

\title{
Lipases as Effective Green Biocatalysts for Phytosterol Esters' Production: A Review
}

\author{
Adejanildo da S. Pereira ${ }^{1}\left(\mathbb{D}\right.$, Aline Habibe de Souza ${ }^{1}$, Jully L. Fraga ${ }^{1}\left(\mathbb{D}\right.$, Pierre Villeneuve $^{2,3} \mathbb{D}^{\mathbb{D}}$, \\ Alexandre G. Torres $4, *,+(\mathbb{D}$ and Priscilla F. F. Amaral $1,+\mathbb{D}$
}

1 Escola de Química, Universidade Federal do Rio de Janeiro, Av. Athos da Silveira Ramos, 149, CT, Bl. E, Ilha do Fundão, Rio de Janeiro 21941-909, Brazil; adejanildosp@gmail.com (A.d.S.P.); alinehabibe.12@gmail.com (A.H.d.S.); jully.lfraga@gmail.com (J.L.F.); pamaral@eq.ufrj.br (P.F.F.A.)

2 Cirad, UMR Qualisud, 34398 Montpellier, France; pierre.villeneuve@cirad.fr

3 Qualisud, Université Montpellier, Cirad, Montpellier Supagro, Université d'Avignon, Université de la Réunion, 34398 Montpellier, France

4 Lipid Biochemistry and Lipidomics Laboratory, Institute of Chemistry, Federal University of Rio de Janeiro, Rio de Janeiro 21941-598, Brazil

* Correspondence: torres@iq.ufrj.br

+ These authors contributed equally to this work.

check for updates

Citation: Pereira, A.d.S.; de Souza, A.H.; Fraga, J.L.; Villeneuve, P.; Torres, A.G.; Amaral, P.F.F. Lipases as Effective Green Biocatalysts for Phytosterol Esters' Production: A Review. Catalysts 2022, 12, 88. https://doi.org/10.3390/ catal12010088

Academic Editors: Natalia Niezgoda and Anna Chojnacka

Received: 29 November 2021

Accepted: 9 January 2022

Published: 13 January 2022

Publisher's Note: MDPI stays neutral with regard to jurisdictional claims in published maps and institutional affiliations.

Copyright: (C) 2022 by the authors. Licensee MDPI, Basel, Switzerland. This article is an open access article distributed under the terms and conditions of the Creative Commons Attribution (CC BY) license (https:// creativecommons.org/licenses/by/ $4.0 /)$.

\begin{abstract}
Lipases are versatile enzymes widely used in the pharmaceutical, cosmetic, and food industries. They are green biocatalysts with a high potential for industrial use compared to traditional chemical methods. In recent years, lipases have been used to synthesize a wide variety of molecules of industrial interest, and extraordinary results have been reported. In this sense, this review describes the important role of lipases in the synthesis of phytosterol esters, which have attracted the scientific community's attention due to their beneficial effects on health. A systematic search for articles and patents published in the last 20 years with the terms "phytosterol AND esters AND lipase" was carried out using the Scopus, Web of Science, Scielo, and Google Scholar databases, and the results showed that Candida rugosa lipases are the most relevant biocatalysts for the production of phytosterol esters, being used in more than $50 \%$ of the studies. The optimal temperature and time for the enzymatic synthesis of phytosterol esters mainly ranged from 30 to $101^{\circ} \mathrm{C}$ and from 1 to $72 \mathrm{~h}$. The esterification yield was greater than $90 \%$ for most analyzed studies. Therefore, this manuscript presents the new technological approaches and the gaps that need to be filled by future studies so that the enzymatic synthesis of phytosterol esters is widely developed.
\end{abstract}

Keywords: lipases; phytosterol esters; biocatalysis; bioactive lipids

\section{Introduction}

The safety level and the consistency of sensory attributes that the food industry has reached contrast to the low nutritional value and low healthiness of processed food, especially fast food and low-cost convenience products. Low-quality food products combined with a sedentary lifestyle, most common in urbanized societies, increase cardiovascular disease risk. In addition, the world has faced several health crises that especially threaten the most vulnerable people, such as individuals with immunodeficiency and metabolic diseases. Several viral epidemics have been recorded in the past 20 years, and emerging ones are expected in the future. Thus, the continuous search for food products and ingredients that may improve human health and prevent serious diseases, such as emerging contagious diseases, while improving overall metabolic health, should be the target of research institutions and industries.

In this context, it is valuable to develop food products and ingredients containing biologically active substances, such as phytosterols. Phytosterols (or plant sterols) are triterpenes with a chemical structure highly similar to cholesterol [1], with more than 
200 homologous compounds [2,3], including $\beta$-sitosterol, campesterol, and stigmasterol, which are the most abundant phytosterols in nature $[4,5]$. These compounds are usually found in plant food rich in lipids, such as peanuts, sesame seeds, fruit and grains, and, mainly, in vegetable oils, such as soybean, canola, and sunflower oils [6]. Phytosterols have been included in dietary prescriptions to lower plasma cholesterol levels, either total or associated with low-density lipoprotein (LDL). Absorption of both bile (endogenous) and dietary (exogenous) cholesterol may be reduced by the intake of plant sterols, without affecting the levels of high-density lipoprotein (HDL) [7-10]. These combined effects would improve the management of blood cholesterol fractions' levels. In addition to these hypocholesterolemic effects, phytosterols also may prevent cancer and atherosclerosis and have anti-inflammatory, antifungal, and antibacterial activity [11].

As the beneficial health effects of phytosterols are under investigation, further bioactive effects are being discovered, in addition to the hypocholesterolemic activity [12], placing these substances in a prominent position as healthy ingredients in food products. However, wide application in the food industry is hindered as phytosterols are insoluble in water and only marginally soluble in oils [13]. Aiming at widening the industrial use and at improving bioaccessibility, phytosterols have been esterified by varied methods to obtain phytosterol esters, facilitating formulations in oily and fatty food systems [14-17]. Phytosterol esters have demonstrated similar physiological effects as phytosterols, with lower melting points and higher oil solubility [1]. These molecules have also been used in food formulations, such as margarine [18], reduced-fat spreads, salad dressings [19], and cheddar cheese [20], with great results concerning tolerance and no adverse effects at daily intake [19] as well as improvements of LDL, HDL, and total cholesterol in plasma $[18,20]$. Synthesis of phytosterol esters can be achieved by esterification with fatty acids or transesterification with their corresponding fatty acid esters by chemical or enzymatic methods [17]. Chemical methods are based on the use of acid [21] or base [22] catalysts, usually associated with high temperatures [13]. Even though these methods produce high yields of phytosterols esters, the formation of many side products and the environmental issues because of chemical wastes, as well as food safety, will limit their use in the near future [23]. Green chemistry can be a choice to reduce the pollution and side reactions of chemical methods, using ionic liquids as catalysts [16]. Lipase-catalyzed phytosterol esters' production offers several advantages in relation to chemical synthesis, especially regarding the mild reaction conditions used and catalyst specificity, which reduce the formation of by-products [24]. It seems a very promising approach but is still on a bench scale because of high production costs, related to the enzyme, and elevated reaction times [21].

Therefore, in this review, we focused on lipase catalysis for phytosterol esters' synthesis, pointing out the recent advances related to enzyme technology to reduce costs and increase productivity/yield and determining the new approaches related to enzymatic ester production and the gaps that deserve to be addressed by future studies.

\section{Lipases}

Of the enzymes with applications in industry, lipases stand out for their diversity of uses, including in the dairy, baking, pulp and paper, polymer, detergent, leather, cosmetics, organic synthesis, and waste management industrial sectors [25]. This is because lipases are not only fast hydrolytic biocatalysts, transforming triacylglycerols into glycerol, monoacylglycerols, diacylglycerols, and fatty acids [26], but they can also catalyze synthesis reactions in media with low water availability [27]. These features, together with high chemo-, regio-, and stereoselectivity at a near-ambient temperature $[27,28]$, make lipases valuable biocatalysts. Besides, lipases are commercially available, and the most widely used in both academia and industry is the immobilized form of lipase B from Candida antarctica (CALB). It can be successfully used in a wide range of reactions and it is a highly stable biocatalyst [29].

Lipases are carboxylic ester hydrolases that act selectively on triacylglycerols and, as such, are classified by the European Commission as EC 3.1.1.3: EC 3, Hydrolases; EC 3.1, 
Acting on ester bonds; EC 3.1.1, Carboxylic ester hydrolases; and EC 3.1.1.3, Triacylglycerol lipase (IntEnz; Integrated relational Enzyme database, available at www.ebi.ac.uk/intenz/, accessed on 29 December 2021). Several hundreds of lipase sequences are listed in databases, and the Protein Data Base (available at www.rcsb.org, accessed on 28 December 2021) has over 200 three-dimensional lipase structures. However, as the same lipase can have several structures in varying conformations or with different substrates, the 221 structures registered in December 2021 represent lipases from 51 known organisms, in addition to 10 structures from metagenomes or unknown organisms. Lipases have been used to catalyze distinct bioconversion reactions: hydrolysis [30], esterification [31], interesterification [32], alcoholysis [33], acidolysis [27], and aminolysis [34]. The ability to synthesize esters of fatty acids and glycerol makes its use appealing in various ester syntheses [35]. In aqueous media, lipases catalyze hydrolysis reactions, but synthesis reactions can occur in media containing limited water availability, such as fluid lipid substrates, organic solvents, non-aqueous supercritical fluids, deep eutectic solvents, and ionic liquids [36] (Figure 1).

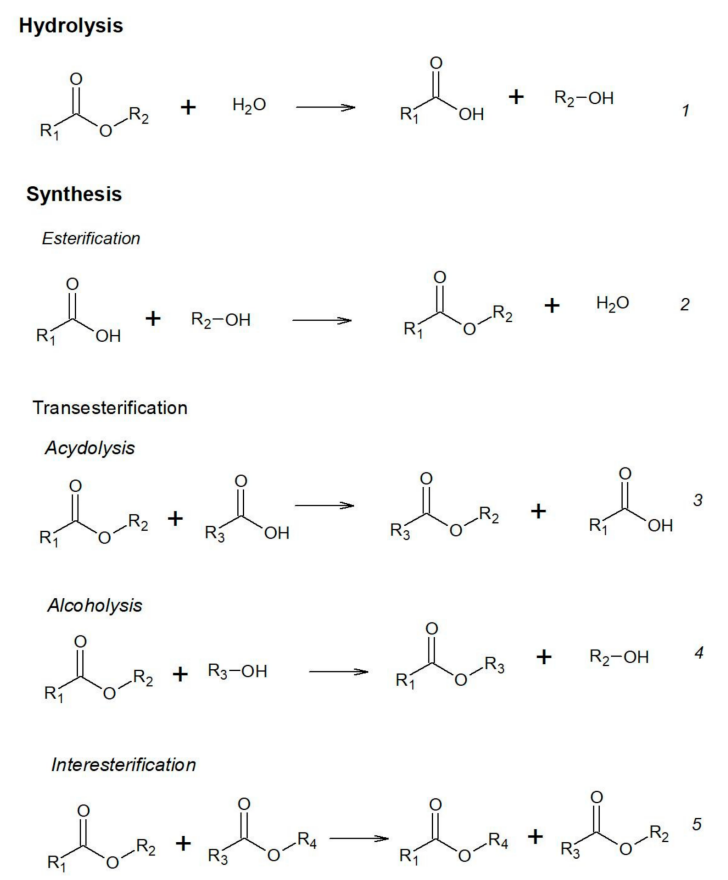

Figure 1. Examples of reactions catalyzed by lipases. Hydrolysis (1) is the most prevalent reaction in aqueous media, whereas synthesis reactions (2-5) can occur in non-aqueous media (ACD/ChemSketch (Freeware) version 2018.2.1, Advanced Chemistry Development, Inc., Toronto, ON, Canada).

Despite having several advantages over chemical catalysts, enzymes are more expensive and usually demand longer reaction times [37]. Culture medium optimization [38,39] and the use of waste materials as substrate source $[38,40,41]$ during the production of microbial lipases may reduce production costs. Genetic manipulation techniques are also valuable tools to supply many enzymes for large-scale processes at affordable prices [28] Besides, numerous immobilization techniques [30,31,42,43] with successful results have been proposed to increase the stability of those biocatalysts, which also influence process costs since they enable the catalyst's reuse for more than a few batches [44]. For example, the thermostability of lipases with different purification levels was significantly increased by immobilization on magnetic nanoparticles, and $70 \%$ of the initial catalytic activity was maintained after 30 reaction cycles [45].

Lipase structure has been reviewed in detail elsewhere [36], and anyone interested in a deeper understanding of lipase structure should refer to this or other extensive reviews on the subject. Characteristically, lipases' structure has a common $\alpha / \beta$ hydrolase fold and a conserved catalytic triad, and most lipases also possess the consensus motif G-X1-S-X2-G. 
During catalysis, the reaction intermediate is stabilized by an oxyanion hole formed with two amino acid residues close to the catalytic triad. The catalytic triad consists of a serine as nucleophile, an acidic residue that can be aspartate or glutamate, and a histidine [46]. Yet other highly conserved features of lipases are the location of the catalytic triad: Serine is in a $\gamma$-like turn in the $\alpha / \beta$ hydrolase fold, after the sheet- $\beta 5$ and before the following $\alpha$-helix [47], aspartate/glutamate locates in a loop after the $\beta 7$-sheet, and the histidine is in a loop after the $\beta 8$-sheet [48]. From the lipases with three-dimensional structures that have been characterized to date, most possess a lid that bends over the active site. The lid is composed of one or more $\alpha$-helices that are joined by a flexible bridge to the main structure of the enzyme. When lipases are in the presence of a lipid-water interface, the lid undergoes conformational changes, uncovering the active site, thus giving access to the substrate [49]. This mechanism is known as interfacial activation and explains why most lipases behave as non-Michaelian catalysts, and sigmoid curves are seen when initial velocity is plotted against substrate concentration. Thus, lipase activity increases sharply when the substrate reaches concentrations high enough to form interfaces such as in micelles and emulsified systems [46]. For surface-activated lipases, mostly by the lid mechanism, the enzyme is inactive in the absence of an interface as the entrance to the active site is blocked.

The active site of lipases is located inside a pocket at the central $\beta$-sheet of the protein structure [50]. The surface of this pocket is enriched with hydrophobic residues, lowering the energy barrier for the hydrophobic substrate. During catalysis, the two amino acids forming the oxyanion hole stabilize the intermediate by forming hydrogen bonds between their backbone amide proton and the oxygen of the substrate carbonyl group. The catalytic mechanism (Figure 2) starts with an acylation, when a proton is transferred between the aspartate (or glutamate), the histidine, and the serine residues of the lipase, activating the hydroxyl group of the catalytic serine. The activated and consequently more strongly nucleophilic hydroxyl group in serine attacks the carbonyl group of the substrate. The first tetrahedral intermediate has a negative charge, and the oxyanion hole stabilizes the charge distribution and reduces the energy state of the tetrahedral intermediate by forming hydrogen bonds. Deacylation then takes place where a nucleophile attacks the enzyme, releasing the product and regenerating the enzyme. The nucleophile here varies and can be water in the case of hydrolysis, an alcohol in the case of alcoholysis or esterification, or an ester or thioester, respectively, in the cases of interesterification or thioesterification.
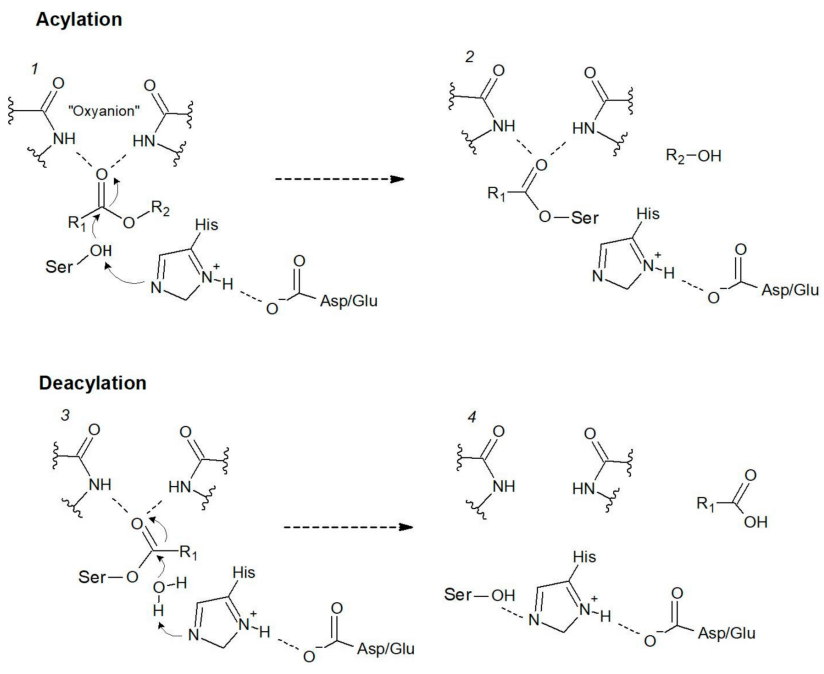

Figure 2. Schematic representation of the mechanism of hydrolysis reactions catalyzed by lipases. The catalytic triad (Ser-His-Asp/Glu) and the oxyanion group are shown, which are conserved structural features of lipases' catalytic site (ACD/ChemSketch (Freeware) version 2018.2.1, Advanced Chemistry Development, Inc.). 
Knowledge of lipase's structure and, most importantly, how it relates to function is essential for biotechnological developments aiming at improved activity, especially by tailoring the enzyme to produce specific products. Recently, Almeida et al. [51] showed that a polyhistidine affinity tag (His-tag) that is frequently used for protein purification purposes modulated the catalytic activity of LipC12 lipase. When the His-tag was preserved after expression, the enzyme was up to 3-fold more effective when used in esterification reactions of medium- and long-chain fatty acids with ethanol. Yixin et al. [52] used directed laboratory evolution to produce lipase B from Candida antarctica (CALB) with the nucleophile exchange Ser $\rightarrow$ Cys, hence changing the catalytic hydroxyl from Ser to a sulfhydryl. The technique of directed evolution promoted additional mutations to the enzyme leading to the selection of a highly active cysteine-lipase having a Cys-His-Asp catalytic triad and additional mutations: W104V/A281Y/A282Y/V149G. This enzyme showed 40-fold higher catalytic activity than the wild-type and acted through a different catalytic mechanism. As this enzyme was active towards bulky substrates, it seems promising for technological use, for instance, in the transesterification of TAG to sterol esters.

Recent advances in protein engineering enable the creation of tailor-made biocatalysts using molecular modeling and site-directed mutagenesis [28] or by directed evolution techniques [53]. Bassegoda et al. [54] reported that rational protein design requires more information about the enzyme, such as enzyme structure and its relationship with sequence and mechanism-function. This information is used to identify specific residues that can be mutated to improve a specific property. The third wave of biocatalysis, related to evolutive biotechnology, can also empower new capabilities of enzymes with less data because it relies on the Darwinian principles of mutation and selection [53]. Directed evolution was used to produce improved lipase B from Candida antarctica (CALB), increasing catalytic activity and enantioselectivity toward profen esters compared to the wild-type enzyme [55]. CALB mutants were also created by directed evolution to improve their resistance towards irreversible thermal inactivation. A 20 -fold increase in half-life at $70^{\circ} \mathrm{C}$ was achieved by two mutants compared with the wild-type CALB, which increased its catalytic efficiency [56].

New insights involving environmentally friendly "green" solvents for catalysis have also been studied with lipases, such as the use of ionic liquids (ILs). Elgharbawy et al. [57] reviewed the use of lipase in ILs and found that it provides numerous technological advantages compared to conventionally used solvents, such as enhanced selectivity, improved enzyme stability, higher conversion rate, and better recovery and recycling of the biocatalyst. These findings showed that there are several innovations that were applied to improve lipase performance, which can be tested for several reaction types, such as phytosterol ester synthesis.

\section{Phytosterol Esters}

\subsection{Roles of Bioactive Compounds}

Bioactive compounds are components of food that interfere with the human organism functioning, via the effects that they promote in human biology when consumed in realistic quantities and when they can be measured properly. In this context, some groups of lipids are called bioactive lipids, including phytosterols, polyunsaturated, conjugated and branched-chain fatty acids, fat-soluble vitamins, and carotenoids [58].

Over the past two decades, it has been shown that bioactive lipids may act as immunomodulators, reducing inflammation and helping to maintain tissue homeostasis, and some are constituents of cell membranes and energy substrates [59]. Via these effects, bioactive lipids help to prevent various diseases, such as cancer, heart disease, obesity, and neurodegenerative disorders [60].

Regarding lipids' structure, fatty acid is the basic unit in the most abundant lipids. Fatty acids' bioactivity depends on structural features, such as chain length, chain branching, and double bonds' number, position, and configuration. The risk of developing metabolic disease can be decreased by consumption of unsaturated fatty acids, via varied biochemical mechanisms. For instance, monounsaturated fatty acids are anti-inflammatory 
and decrease plasma LDL levels while simultaneously decreasing the chance of LDL oxidation, which is a major cardiovascular disease promoter. Polyunsaturated fatty acids are more effective in decreasing LDL levels in plasma, especially omega-3 fatty acids that have the additional benefit of being anti-inflammatory, in contrast to omega- 6 that can be pro-inflammatory. Conjugated fatty acids might improve the plasma lipoprotein profile and show immunomodulatory activity [61]. Therefore, lipid formulations containing bioactive fatty acids combined with plant sterols might present added benefits to health, especially in the prevention of chronic metabolic disease.

\subsection{Phytosterols}

Plant sterols are bioactive compounds from plants that tend to be concentrated in the lipid enriched parts, such as oilseeds and fat-rich fruit. Phytosterols belong to the class of triterpenes and have a similar structure to that of cholesterol, which is the most abundant sterol in animal cells. Phytostanols are also plant triterpenes structurally similar to phytosterols, differing only for a carbon-carbon double bond in the B-ring that lacks in the former class of compounds. Phytostanols are also bioactive but, as they are much less concentrated in food, and there are much fewer published studies on phytostanols, we decided to focus on phytosterols in this review. In western populations, the major dietary source of phytosterols is plant oils such as soybean, corn, canola, and wheat germ oil [62], but nuts are concentrated in these steroids and can be the major dietary source depending on dietary habits. Stigmasterol, $\beta$-sitosterol, and campesterol are phytosterols most recognized as bioactive in humans [63].

Several studies have been carried out in the last decades and it is now known that phytosterol intake effectively reduces blood cholesterol, in addition to having antioxidant and anti-inflammatory properties, contributing to the attenuation of metabolic diseases, especially cardiovascular. Thus, a worldwide effort has begun to regulate plant sterols' use in food and dietary supplements, for instance, concerning safe levels and health claims [64].

However, owing to phytosterols' low solubility in water and in oils, direct application in the food industry is limited. Phytosterols are insoluble in water, and their solubility in fats and oils is close to $1 \mathrm{~g} / 100 \mathrm{~g}$. To overcome this limitation, esterification of a fatty acid to the single hydroxyl of plant sterols has been studied as an approach to increase lipid solubility and facilitate food formulations [17]. For instance, He et al. [65] reported that, by the esterification with linoleic acid, the solubility of phytosterols in oils was improved by 18 times. The esterification of phytosterols not only increases their solubility in oily solutions, but also decreases their melting point and improves flavor and bioavailability [66]. Phytosterols have melting points above $140{ }^{\circ} \mathrm{C}$, but their melting point can be reduced to $25^{\circ} \mathrm{C}$ after esterification with oleic acid, for example [67].

Chemical and biological syntheses are the two main methods employed. Chemical synthesis has a good conversion rate; however, it can generate by-products due to the low specificity of chemical catalysts and to the requirements of using high temperatures to promote high conversion rates. Biocatalysts, despite the lower yields, require much lower temperatures, and produce much fewer by-products owing to their catalytic specificity [17].

\subsection{Synthesis of Phytosterols' Esters}

Phytosterol esters of fatty acids are currently synthesized by a direct esterification with fatty acids or transesterification with their corresponding fatty acid esters by chemical or enzymatic methods. The chemical synthesis with homogeneous catalysts makes use of high temperatures with strong acids $\left(\mathrm{H}_{2} \mathrm{SO}_{4}, \mathrm{H}_{3} \mathrm{PO}_{4}, p\right.$-toluenesulfonic acid) or alkali $(\mathrm{NaOEt}, \mathrm{NaOH}, \mathrm{KOH}, \mathrm{NaOMe}$ ) as catalysts (Figure 3). For instance, concentrated sulfuric acid was used as a catalyst for the esterification of phytosterol with oleic acid at $170{ }^{\circ} \mathrm{C}$, achieving a conversion rate of over $98 \%$ after $2 \mathrm{~h}$, but with $18.8 \%$ of by-products [68]. These authors also tested the transesterification with $\mathrm{NaOMe}$ as catalyst and obtained almost $99 \%$ of conversion rate, after $4 \mathrm{~h}$, and $26.7 \%$ of by-products [68]. 


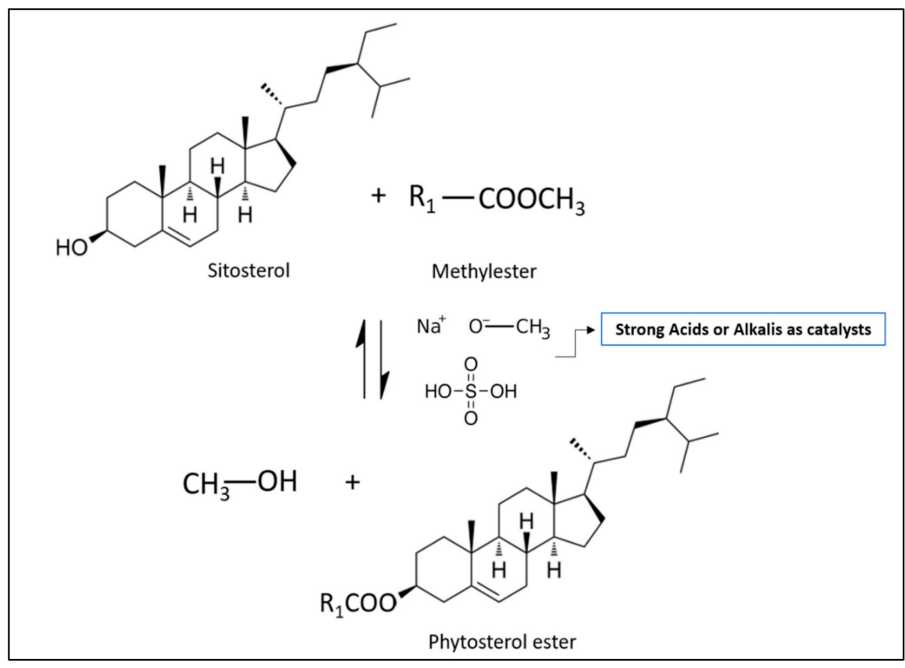

Figure 3. Scheme of phytosterol esters' synthesis.

Chemical synthesis is currently the only economically viable process used to produce phytosterol esters, despite the inherent problems in these processes [21]. Chemical catalysis can be significantly efficient to obtain phytosterol esters [21,68]; however, there are numerous drawbacks, mainly related to by-product formation (dienes, trienes, or phytosterols oxides) and the hazardous catalyst residues. By-products' formation leads to reduced yield and increased complexity in downstream processes. Removal of the chemical catalyst is difficult and often incomplete, in this case resulting in a persistent catalyst in the product. The persistence of by-products and residual catalysts may impact product quality and safety, which is a major concern in the case of food products [68]. Additionally, the effluents formed and the residual catalyst cause a large, negative environmental impact [69].

Virtually all studies on esterification of phytosterols have aimed at reducing the amounts of residues generated and the environmental impacts and at increasing the reaction yield. Almost 40 years ago, Saroja et al. [70] described the synthesis of sterol fatty acid esters catalyzed by chlorine, bromine, thionyl chloride, or anhydride derivatives of fatty acids. However, these catalysts are no longer acceptable to produce food additives.

Pouilloux et al. [22] investigated the ability of magnesium or zinc oxides in heterogeneous catalysis to transesterify $\beta$-sitosterol with methyl dodecanoate in a solvent-free medium. In this study, the alkaline solid catalyst yielded $75 \%$ sterol ester after $7 \mathrm{~h}$ at $240{ }^{\circ} \mathrm{C}$ and showed reuse potential. However, the strong alkaline sites of magnesium oxide favored the side reaction of sitosterol dehydration.

In 2006, Meng et al. [21] proposed an innovative scalable route for phytosterol esters' synthesis in a solvent-free medium, using four heteropolyacids, and avoiding sodium methylate as catalyst. The yield of phytosteryl ester was higher than $90 \%$ when the reaction was carried out at $150{ }^{\circ} \mathrm{C}$, at a 1:1.5 phytosterol:fatty acid molar ratio and catalyzed by $0.2 \%$ tungstosilicic acid on silica gel. The immobilized tungstosilicic acid was reused in six sequential runs without losing its activity [21]. In a latter study, Meng et al. [68] obtained a maximum production of steryl oleates near $98 \%$ after $8 \mathrm{~h}$ at $170{ }^{\circ} \mathrm{C}$, using aluminasupported zinc oxide $\left(\mathrm{ZnO} / \mathrm{Al}_{2} \mathrm{O}_{3}\right)$ to esterify free oleic acid and phytosterol ( $95 \%$ purity), in a 2:1 molar ratio.

Another innovative method was applied for the synthesis of phytosterol esters by Nguyen et al. [23], which was also more sustainable. The microwave-mediated, noncatalyzed approach resulted in a $95.4 \%$ conversion of free phytosterol to esters after $50 \mathrm{~min}$ at $180^{\circ} \mathrm{C}$, at $200-\mathrm{W}$ microwave power, and 5:1 oleic acid:phytosterols molar ratio. The noncatalytic esterification by microwave irradiation was ecologically friendly and can produce high-quality phytosterol esters, avoiding the inconveniences resulting from the use of a chemical catalyst, especially catalyst and by-products' removal from the reaction medium. 
In the last decade, enzyme-catalyzed synthesis of phytosterol esters has attracted much interest because of mild reaction conditions, selectivity, and the formation of less numerous and lower amounts of by-products. Numerous lipases have been successfully used for the synthesis of phytosterol esters, which will be the subject of the next topic.

\section{Biocatalysis in the Synthesis of Phytosterol Esters}

\subsection{General Aspects}

Several stearic enzymes have been successfully tested for the synthesis of phytosterol esters, with lipases as the most [71]. Esters produced with biocatalysts can be considered "green" products and satisfy the recent demand for sustainability [72]. Thus, to produce phytosterol esters, biocatalysis provides a good way to obtain the mandatory quality for use in food. Biocatalysis of phytosterol esters can be performed by direct esterification or by transesterification (Figure 4 ).
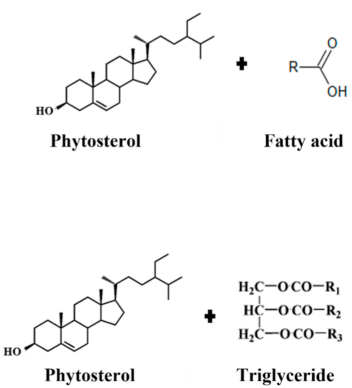

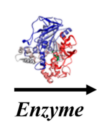

(a)

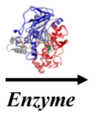

Enzyme

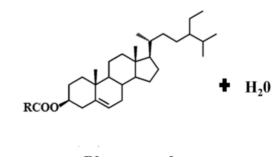

Phytosterol ester

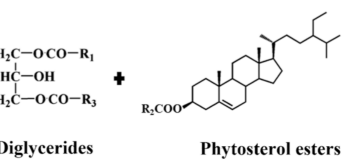

(b)

Figure 4. Synthesis of phytosterol esters by direct esterification to free fatty acids (a) and transesterification with triacylglycerols (b) in the presence of a biological catalyst.

A systematic search for the terms "Phytosterol AND esters AND lipase" in articles published in the last 20 years (2001-2021) was performed using the Scopus, Web of Science, Scielo, and Google Scholar databases. The papers retrieved were critically evaluated, and those related to the enzymatic synthesis of these molecules were selected. Reviews and original papers related to chemical synthesis, nutritional and medical effects, physicochemical properties, analytical procedures, and economic aspects were excluded. The final set of articles contained 66 documents, which were the object of our analysis (Table 1). More than $85 \%$ of these studies used direct esterification as the main reaction strategy. The process conditions and results reported in these studies are summarized in Table 1.

Table 1 shows that Candida rugosa lipases are the most relevant biocatalysts to produce phytosterol esters, being used in more than $50 \%$ of the studies found in Scopus, Web of Science, Scielo, and Google Scholar databases. C. rugosa lipases are commercially available, usually as a mixture of isoenzymes, and are among of the most frequently used enzymes in biotransformations [138]. Lipase B from Candida antarctica (CALB), the most used commercial lipase, is also identified in Table 2 in a work performed by Yu et al. [76] in 2019, with high conversion values (93.2\%). Additionally, He et al. [65] compared this enzyme with C. rugosa lipase for the transesterification of phytosterols with ethyl linolenate and obtained a conversion four times lower than for CALB. The esterification conversions were also high for most of the studies reviewed (Table 2), some of them reaching more than 95\%, which is near to the conversions of chemical reactions. Low reaction times were found in those studies (Table 1), especially with C. rugosa lipase, with which many were lower than $2 \mathrm{~h}[65,78,84,86,88]$. These results showed that the use of enzymes for the synthesis of phytosterol esters is very promising. 
Table 1. Synthesis of phytosterol esters using enzymatic catalysts.

\begin{tabular}{|c|c|c|c|c|c|c|}
\hline Product & Enzyme & Solvent & Temperature $\left({ }^{\circ} \mathrm{C}\right)$ & Time (h) & Conversion (\%) & Ref. \\
\hline $\begin{array}{l}\beta \text {-sitosterol } \\
\text { laurate }\end{array}$ & Candida rugosa lipase & Isooctane & 47 & 48 & $88.12 \pm 0.79$ & [73] \\
\hline Functional oil & $\begin{array}{c}\text { Candida rugosa and } \\
\text { Thermomyces lanuginosus } \\
\text { lipase }\end{array}$ & $n$-heptane & 40 & 8 & - & [74] \\
\hline Stigmasteryl oleate & Candida rugosa lipase & Petroleum ether & 45 & 16 & 97.33 & [75] \\
\hline Rice bran oil & Novozym 435 & Solvent-Free & 78 & 41 & 93.2 & [76] \\
\hline$\beta$-sitosterol linolenate & Candida rugosa lipase & Isooctane & 29.5 & 6 & $96.8 \pm 0.7$ & [77] \\
\hline Phytosterols linolenate & Candida rugosa lipase & Solvent-Free & 50 & 1.17 & $90.0 \pm 2$ & [78] \\
\hline Rice soybean oil & Candida antarctica lipase B & Solvent-Free & 50 & 3 & 86.2 & [79] \\
\hline Phytosterol ester & Candida rugosa lipase & Cyclohexane & 30 & 8 & 81.0 & [80] \\
\hline Phytosterol oleate & Candida rugosa lipase & Isooctane & 50 & 6 & 96.5 & [81] \\
\hline Phytosterol oleate & Yarrowia lipolytica lipase & Solvent-free & 50 & 72 & 91.1 & [82] \\
\hline Phytosterol ester & Candida rugosa lipase & n-heptane & 44 & 12 & $90.8 \pm 0.4$ & [83] \\
\hline Phytosterol Linolenate & Candida rugosa lipase & Isooctane & 40 & 2 & $95.9 \pm 0.8$ & [65] \\
\hline Phytosteryl Ester & Candida rugosa lipase & $n$-hexane & 40 & 0.05 & 90.0 & [84] \\
\hline Phytosteryl laurate & Candida rugosa lipase & $n$-hexane & 50 & 48 & 95.1 & [85] \\
\hline Phytosterol oleate & Candida rugosa lipase & Isooctane & 50 & 1 & 95.4 & [86] \\
\hline Functional Oil & Candida rugosa lipase & Hexane & 50 & 12 & $>92.1$ & [87] \\
\hline Phytosterol oleate & Candida rugosa lipase & - & - & 0.6 & 75.26 & [88] \\
\hline Phytosterol oleate & Candida rugosa lipase & - & 30 & 24 & 80.0 & [89] \\
\hline Phytosteryl ester & Candida rugosa lipase & Solvent-free & 60 & 1.5 & 93.0 & [90] \\
\hline$\beta$-sitosteryl esters & Candida antarctica lipase & Hexane & $40-50$ & 24 & $93.0-98.0$ & [91] \\
\hline Phytosterol esters & Candida rugosa lipase & Isooctane & 50 & 7 & $>92.1$ & [92] \\
\hline Phytosterol laurate & Candida rugosa lipase & $n$-hexane & 40 & 10 & 96.6 & [93] \\
\hline Phytosterol oleate & Candida sp. lipase & Isooctane & 45 & 24 & 93.4 & [94] \\
\hline Phytosterol esters & Candida rugosa lipase & Isooctane & $40-55$ & $6-24$ & $>80.0$ & [95] \\
\hline Phytosteryl esters & $\begin{array}{c}\text { Candida rugosa and } \\
\text { Pseudomonas stutzeri lipase }\end{array}$ & Solvent-free & $50-60$ & $3-4$ & $>90.0$ & [96] \\
\hline Phytosteryl Caprylates & Candida rugosa lipase & $n$-hexane & 45 & 9 & 98.0 & [97] \\
\hline Phytosterols linolenate & Candida rugosa lipase & Isooctane & 55 & 15 & 93.5 & [98] \\
\hline Phytosteryl esters & Pseudomonas stutzeri lipase & $\begin{array}{c}\text { Free and exogenous } \\
\text { solvent }\end{array}$ & 50 & - & - & [99] \\
\hline Phytosteryl esters & Different enzymes & Solvent-free & 25 and 50 & $4-312$ & $5.0-97.0$ & [100] \\
\hline$\beta$-sitosterol esters & $\begin{array}{c}\text { Thermomyces lanuginosus } \\
\text { lipase }\end{array}$ & - & $40-65$ & $3-24$ & - & [101] \\
\hline Phytosteryl linolenate & Candida rugosa lipase & Solvent-free & $35-40$ & - & $<80$ & [102] \\
\hline Phytosteryl esters & Candida rugosa lipase & Solvent-free & 50 & 9 and 48 & $94.0-99.0$ & [103] \\
\hline Phytosterol oleate & Candida rugosa lipase & $n$-hexane & 51 & 17 & 97.0 & [104] \\
\hline Phytosterol oleate & Different enzymes & $n$-hexane & 35 & $24-72$ & $<85.0$ & [105] \\
\hline Sitosteryl esters & Different enzymes & $\begin{array}{l}\text { With or without } \\
\text { solvent }\end{array}$ & 55 & 48 & $<30.0$ & [106] \\
\hline Phytosterol ester & Alcaligenes sp. lipase & Solvent-free & 100 & 7 & 97.1 & [107] \\
\hline Phytosteryl linolenate & Rhizomucor miehei lipase & - & 50 & 24 & - & [108] \\
\hline Phytosterol ester & Candida rugosa lipase & Solvent-free & 35 & 5 & 90.0 & [109] \\
\hline Phytosterol ester & Candida rugosa lipase & isooctane & 55 & - & 93.6 & [110] \\
\hline Phytosterol ester & Proteus vulgaris K 80 lipase & hexane & 40 & 3 & 71.0 & [111] \\
\hline Phytosterol ester & Novozyme 435 lipase & - & 101 & 3 & 85.6 & [112] \\
\hline Phytosterol laurate & - & - & 45 & 48 & 94.6 & [113] \\
\hline Ergosterol linolenate & Candida sp. 99-125 lipase & isooctane & 45 & 12 & 92.0 & [114] \\
\hline Phytosterol ester & Candida rugosa lipase & Solvent-free & 55 & 1.5 & 95.0 & [115] \\
\hline Phytosterol ester & Lipase AYS & Isooctane & 45 & 0.16 & 90.0 & [116] \\
\hline Functional oil & Candida rugosa lipase & Isooctane & 55 & 2 & 85.0 & [117] \\
\hline Phytosterol ester & Candida rugosa lipase & Isooctane & 50 & 2 & 96.8 & [118] \\
\hline Phytosterol ester & Lipozyme 435 lipase & $n$-hexane & 55 & 20 & 93.0 & [119] \\
\hline $\begin{array}{c}\text { Phytosteryl } \\
\text { docosahexaenoates }\end{array}$ & Pseudomonas sp. lipase & $n$-hexane & - & 24 & 96.0 & [120] \\
\hline Phytosteryl lipoate & Candida rugosa lipase & $\begin{array}{c}2 \text {-metil-2- } \\
\text { butanol } / n \text {-hexano }\end{array}$ & 55 & 96 & 71.2 & [121] \\
\hline Steryl hydroxycinnamates & Candida rugosa lipase & $n$-hexane & 63 & 120 & 55 & [122] \\
\hline Functional oil & Candida antarctica lipase & - & - & - & 87.4 & [123] \\
\hline Phytosterol ester & Candida rugosa lipase & n-hexane & 45 & 48 & 84.7 & [124] \\
\hline$\beta$-sitosterol linolenate & $-n^{2}-1$ & n-hexane & 50 & 72 & 72.6 & [125] \\
\hline Phytosterol ester & Candida rugosa lipase & Solvent-free & 55 & - & 90.0 & [126] \\
\hline Linoleyl $\beta$-sitosterol & Candida antarctica lipase & n-hexane & 50 & 72 & 72.6 & [127] \\
\hline Phytosterol myristate & Lipase AYS & n-hexane & 50 & 72 & 69.9 & [128] \\
\hline Phytosterol palmitate & Novozyme 435 lipase & n-hexane & 55 & 72 & 36.9 & [129] \\
\hline Functional oil & Novozyme 435 lipase & Solvent-free & 85 & 1 & 92.0 & [130] \\
\hline Phytosterol ester & $\begin{array}{l}\text { Pseudomonas } \\
\text { lipase }\end{array}$ & - & 55.5 & 41.2 & 84.4 & [131] \\
\hline Phytosterol ester & Candida rugosa lipase & n-hexane & 40 & 87 & 97.5 & [132] \\
\hline Phytosterol linolenate & Novozyme 435 lipase & Isooctane & 55 & 24 & 40.6 & [133] \\
\hline Phytosterol ester & Candida antarctica lipase & - & 50 & 72 & 85.7 & [134] \\
\hline Phytosterol laurate & - & Solvent-free & 60 & 12 & 92.2 & [135] \\
\hline Functional oil & $\begin{array}{c}\text { Thermomyces lanuginosus } \\
\text { lipase }\end{array}$ & n-hexane & 60 & 25 & - & [136] \\
\hline Phytosterol ester & Canadia sp. 99-125 lipase & Isooctane & 60 & 8 & 85.7 & [137] \\
\hline
\end{tabular}


Chemoenzymatic methods have also been reported in some studies. Tan and Shahidi [97] studied the chemoenzymatic synthesis of phytosteryl caffeates by means of an intermediate caffeate vinyl, which was initially produced chemically and later esterified with phytosterols by lipase-assisted alcoholysis. In another study, Tan and Shahidi [139] chemoenzymatically synthesized two new groups of phytosteryl phenolates: phytosteryl sinapates and vanillates.

Table 2. Patents registered in the last 20 years about the synthesis of phytosterol esters.

\begin{tabular}{cccc}
\hline Title & Inventors & Registration Number & Registration Date \\
\hline $\begin{array}{c}\text { Method for preparing functional edible oil rich in } \\
\text { phytosterol esters and diglycerides }\end{array}$ & {$[140]$} & US20150289534A1 & 15 October 2015 \\
$\begin{array}{c}\text { Method for producing fatty acid phytosterol ester using } \\
\text { immobilized lipase derived from Candida rugosa }\end{array}$ & {$[141]$} & KR101550101B1 & 30 April 2015 \\
$\begin{array}{c}\text { Method for producing phytosterol/phytostanol } \\
\text { phospholipid esters }\end{array}$ & KR20150046397A & 4 September 2015 \\
$\begin{array}{c}\text { Method for producing plant sterol ester by immobilized } \\
\text { whole-cell enzyme catalysis in solvent-free system }\end{array}$ & [143] & WO2010109441A1 & 30 September 2010 \\
\hline
\end{tabular}

Some patents related to the biocatalysis of phytosterol esters have also been granted in the past 20 years. The search for "Phytosterol AND esters" in the title and abstract of these texts in the Espacenet database led to 85 results, four of which dealt with biocatalysis (Table 2).

Table 2 shows that C. rugosa lipase was also identified in those patents, indicating that, indeed, this is a good biocatalyst for industrial production of phytosterol esters. These studies, articles, and patents show that the synthesis of phytosterol esters by biocatalysis is a green process with great potential to be used in the industrial production of these products. However, to obtain high yields, it is necessary to analyze the variables that influence the reaction performance.

\subsection{Parameters Affecting the Biocatalytic Synthesis of Phytosterols' Esters}

Operational parameters such as temperature, substrates' molar ratio, enzyme loading and source, reaction time, stirring efficiency, and the reaction medium are known to cause a great impact on biocatalytic processes and, therefore, they will be evaluated in the next topics.

\subsubsection{Effect of Temperature}

Temperature control is crucial to obtain a high-performance enzyme catalyst. Temperature increase contributes to solubilizing reagents, reducing mixture viscosity, increasing molecular collision, reducing mass transfer limitations, and to improve the interactions between enzyme and substrate [71]. However, enzymes express maximum performance at optimal temperatures, and missing these temperatures can lead to a reduction in catalytic activity and structural stability. For heterogeneous catalysis, typical of biocatalytic processes that use immobilized enzymes, the reaction usually occurs on the catalyst surface in which the molecular reagent adsorbs, diffuses, activates, reacts, and desorbs to form the final products [144]. Higher temperature increases diffusivities and reduces viscosities, enhancing the mass transfer of substrates to the enzymes. Therefore, immobilized systems require larger activation energy when compared to the same process under homogeneous conditions. However, enzyme stability is higher at elevated temperatures in low-water environments compared to aqueous solutions [145] and also for immobilized catalysts as compared to the free enzyme [45].

In phytosterol esters' production by enzymes, the temperature is set in the range of 30 to $101{ }^{\circ} \mathrm{C}$, depending on the lipase used (Table 2). Chen et al. [73] evaluated the effect of temperature $\left(35\right.$ to $60{ }^{\circ} \mathrm{C}$ ) on the yield of $\beta$-sitosterol laurate production using Candida rugosa lipase and observed a substantial increase from 34 to $56 \%$ when the temperature changed from 35 to $45^{\circ} \mathrm{C}$. The authors subsequently observed a slight decline to $49 \%$ after further 
increasing the temperature to $50{ }^{\circ} \mathrm{C}$, and then a major decline to $26 \%$ at $55^{\circ} \mathrm{C}$ and finally to $3 \%$ at $60{ }^{\circ} \mathrm{C}$. They attributed this reduction to the denaturation and inactivation of the enzyme but also to the changes of the reaction medium properties into an inappropriate reaction system [45]. Probably the use of a reverse micelle system that combines an aqueous dispersed phase and a nonaqueous continuous phase with the assistance of amphiphilic molecules, was not ideal for a temperature increase since thermostability of free enzymes is usually lower than immobilized systems [73]. He et al. [65] studied the effect of temperature on the synthesis of phytosterol linolenate catalyzed by lyophilized C. rugosa lipase and observed that increasing temperature improved the substrate solubility, but the catalytic activity and stability of the enzyme were strongly affected. At $50{ }^{\circ} \mathrm{C}$, phytosterol linoleate conversion was more than three times the conversion with immobilized enzymes Novozyme 435 and Lipozyme RM IM, but the optimal temperature for the ester conversion by lyophilized Candida rugosa lipase was $40{ }^{\circ} \mathrm{C}$ [65].

Cui et al. [82] also evaluated the influence of temperature on the synthesis of phytosterol oleate using Y. lipolytica lipase immobilized in celite by adsorption. The authors found that the increase in the reaction temperature from 30 to $50^{\circ} \mathrm{C}$ resulted in a corresponding increase in the esterification yield, with a maximum conversion of $85 \%$ at $50{ }^{\circ} \mathrm{C}$. Temperatures above $50{ }^{\circ} \mathrm{C}$ did not improve the esterification yield. High $\left(101^{\circ} \mathrm{C}\right)$ temperatures have been used with immobilized lipases, such as Novozyme 435 [112], but conversion did not improve much (maximum $85.6 \%$ ). Higher conversion $(>90 \%)$ and reduction in the reaction time $(1 \mathrm{~h})$ could be achieved with this enzyme at a lower temperature $\left(85^{\circ} \mathrm{C}\right)$ in supercritical carbon dioxide [130]. Microwave irradiation could also help C. rugosa lipase immobilized in $\mathrm{ZnO}$ nanowires/macroporous $\mathrm{SiO}_{2}$ composites to increase conversion $(>95 \%)$ and reduce reaction time $(1 \mathrm{~h})$ in the synthesis of phytosterol ester at low temperature $\left(50^{\circ} \mathrm{C}\right)$ [86]. These strategies increase substrate solubilities without the need to increase temperature as much, which is good for enzyme activity [86,130].

\subsubsection{Effect of Substrate Molar Ratio}

The study of molar ratio is a particularly important parameter for any biocatalysis system that aims at high yields without reducing enzyme activity or wasting reagents [71]. The molar ratio is the ratio between the acyl donor (for example, fatty acids) and the acyl acceptor (for example, phytosterol).

Normally, increasing the substrate mole ratio significantly improves the esterification yield. This is due to the change in the esterification equilibrium, referred to as the Le Chatelier principle, which has been widely recognized in the esterification reaction [73,146,147]. In theory, this principle indicates that the excess of the equivalent molar amount of one of the substrates causes a change in the reaction equilibrium towards the direction where the product is formed [73]. However, the increase in the substrate molar ratio can influence other characteristics of the reaction medium, such as $\mathrm{pH}$ and solubility, which can affect the reaction negatively.

Several studies have evaluated the effect of substrate molar ratio to maximize the esterification yield and avoid waste $[65,73,84,90,93,95]$. Liu et al. [77], studying the $\beta$-sitosterol linolenate production, observed that the increase in linolenic acid concentration showed a tendency for rapid growth in the conversion rate. However, when the linolenic acid concentration exceeded $40 \mathrm{mmol} / \mathrm{L}$, there was a reduction, indicating that the reaction reached an equilibrium point.

A rapid increase in the esterification yield of $\beta$-sitosterol laurate (33.74 to $52.90 \%$ ) was observed as the substrate mole ratio increased from 1:1 to 1:3, without significant results when it was increased to 1:5 [73]. The authors attributed this fact to an increase in acidity and a decrease in the solubility of the reaction medium.

Dong et al. [78] observed that for phytosterol linolenate production, a molar ratio of $1: 2$ yielded $30 \%$ of esterification, while a subsequent increase to 1:3 and 1:4 yielded $90 \%$. For the phytosterol oleate synthesis, a molar ratio of 1:1 (oleic acid:phytosterols) converted only $62.1 \%$ of phytosterol, while for a molar ratio of $2: 1,84.2 \%$ was obtained [81]. 


\subsubsection{Enzyme Source and Load}

The source and amount of enzyme strongly affect the technical-economic viability of phytosterol esters' synthesis processes. The lipases most used in obtaining phytosterol esters are those produced by C. rugosa, as previously mentioned (Table 2).

C. rugosa lipases are commercialized in mixtures of isoenzymes, mainly Lip1, Lip2, and Lip3, which are stabilized with lactose that plays an important role as a water reservoir [138], and might be the reason for its success in those reactions since it can protect the enzyme in a low-water content environment [93]. The active site in CRL is covered by the $\alpha$-helix lid, composed of amino acids with amphiphilic properties, which is essential for the catalytic enzymatic activity and/or enantioselectivity [138], another advantage for esterification reactions.

Other enzymes can also be studied, considering that they must be compatible with low-water content media because trace water is needed for enzymatic catalysis in a nonaqueous phase. Covalent modification of the lipase surface has been performed by some researchers to improve enzymatic activity and stability in those media [148]. However, this approach may change the structure of the enzyme molecules, causing irreversible loss of enzymatic activity. Jiang et al. [93] used macroporous resins for C. rugosa lipase adsorption (immobilization) and added trehalose during the enzyme-catalyzed reaction of phytostanols' esterification to protect the enzyme. The aqueous solution of trehalose was attached to a site-directed area of the lipase surface, which is generally hydrophilic and far from the active site due to the expulsion from the hydrophobic solvent. As a result, the esterification reached $96.6 \%$ after $10 \mathrm{~h}$.

A different lipase was tested with promising results: The lipase from Ophiostoma piceae catalyzed $\beta$-sitostanol ester synthesis via transesterification with the yield of $80-90 \%$ in $1 \mathrm{~h}$ at nearly room temperature [149].

Another important enzyme feature is its form, that is, immobilized or free. Immobilized enzymes have been used preferentially, as they generally improve the performance of these biomolecules as well as allowing their reuse, which contributes greatly to reducing the process cost $[79,81,98]$.

C. rugosa lipase immobilized on macroporous resins by Jiang et al. [93] was able to maintain the esterification rate above $85.0 \%$ after six recycles. The immobilization of C. rugosa lipase was also performed on the mixed-mode silica particles via hydrophobic and strong cation-exchange interaction, which increased its stability remarkably at high temperature in comparison to free enzyme [98]. The immobilized lipases could reach a degree of $95.3 \%$ of phytosterols' linolenate esterification and retained $78.6 \%$ of their initial activity after seven recycles [98].

Phytosterol ester was synthesized using Yarrowia lipolytica lipase Ylip2 immobilized on celite in a solvent-free system and retained $90 \%$ esterification activity for the synthesis of phytosterol oleate after eight reuse cycles, while free lipase was only viable for five batches [82]

High enzymes' loading is not recommended in esterification reactions, as it can cause agglomeration, which can lead to substrate site blocking [150]. In addition, it can increase the viscosity of the reaction medium, too, much by limiting mass transfer [150].

There are many studies on the effect of enzyme loading in the production of phytosterol esters. Chen et al. [73] varied the amount of C. rugosa lipase from 3 to $30 \%$ (total $w / w$ of reagents) to produce $\beta$-sitosterol laurate and observed a great increase in the esterification yield ( 17.83 to $65.48 \%$ ) when the enzyme amount was increased from 3 to $15 \%$. However, the continuous increase in enzyme load to $30 \%$ did not improve the yield.

He et al. [65] also evaluated the influence of the C. rugosa lipase amount (5 to $40 \mathrm{~g} / \mathrm{L}$ ) on phytosterol linolenate production and observed that an increase in enzyme dosage from 5 to $20 \mathrm{~g} / \mathrm{L}$ resulted in a significant improvement in conversion (40.6 to $90.4 \%$ ). The authors also observed that the additional increase from 20 to $40 \mathrm{~g} / \mathrm{L}$ did not improve the results, indicating that $20 \mathrm{~g} / \mathrm{L}$ of Candida rugosa lipase was ideal for the process. A similar trend 
was found in the study by Zheng et al. [98], who observed that the highest production of phytosterol esters was obtained using $15 \mathrm{~g} / \mathrm{L}$ of immobilized C. rugosa lipase.

\subsubsection{Effect of Reaction Medium}

Esterification reaction is greatly influenced by the presence of water because the equilibrium by hydrolytic enzymes is in favor of hydrolysis, that is, the reverse reaction [71]. Thus, for phytosterol esters' synthesis, a water-free reaction medium enables high conversion rates. However, esterification reactions produce water as a by-product. In this sense, some strategies are adopted to minimize water content.

The use of organic solvent has been one of the most used approaches, with the advantages of increasing substrate concentration and solubility and also changing the thermodynamic reaction equilibrium to favor esterification over hydrolysis $[151,152]$. The right choice of solvent is also of crucial importance in the process; therefore, the log $\mathrm{P}$ (logarithm of the partition coefficient of a solvent in the octanol/water mixture) is a widely used parameter to evaluate the effect of organic solvents on esterification yield [70]. Solvents having $\log \mathrm{P}<2$ are hydrophilic and, hence, are not expected to be very suitable for biocatalysis [145]. Lipases are generally more unstable in polar solvents miscible in water [153] because they remove water from the hydration layer of enzymes, disrupting enzyme conformation causing inactivation [154]. Solvents with $\log P$ values between 2 and 4 are much less hydrophilic, but the predictability for solvent suitability is poor in this region. With higher $\log \mathrm{P}$ values, the solvents become hydrophobic and, therefore, are the best hosts for biocatalysis [145]. The non-polar solvents probably change the equilibrium from the closed to the open conformation of the enzyme and also modify the solubility of substrates and products in the reaction medium, favoring conversion [155]. However, $\log \mathrm{P}$ is not the only parameter affecting enzyme activity in an organic solvent system, but the cumulative effect of several other parameters, such as dielectric constant, dipole moment, hydrogen bonding, and polarizability [156], and, therefore, the reaction medium and solvent type also influence the conversion.

For phytosterol esters' synthesis, the use of higher $\log \mathrm{P}$ solvents has been reported as a better choice. Lipases, the main enzymes used in phytosterol esters' synthesis, usually exhibit greater catalytic activity and operational stability in higher $\log \mathrm{P}$ solvents $[67,74,87,92,157]$. Zheng et al. [95] evaluated solvents with different log P values (n-hexane, isooctane, cyclohexane, and tert-amyl alcohol) for the synthesis of phytosterol linolenate and observed that isooctane, the solvent with the highest $\log \mathrm{P}(\log \mathrm{P}=4.5)$, was the best solvent for the esterification.

Chang et al. [75] studied the effect of different solvents on the esterification yield of stigmasterol oleate and observed that the esterification rate obtained with petroleum ether $(\log P=0.89)$ was significantly higher than with other solvents: $n$-heptane $(\log P=4.0)$; isooctane $(\log \mathrm{P}=4.5)$; and $\mathrm{n}$-hexane $(\log \mathrm{P}=3.5)$. This surprising result was attributed to the higher solubility of stigmasterol in petroleum ether.

Although organic solvents are important in esterification reactions, the use of these substances can exhibit some drawbacks associated with the costs of separation and the presence of residual toxic substances to human health at the final product. Thus, the production of phytosterol esters in solvent-free media has been gaining importance in recent years $[82,96,100,158]$. In these studies, different strategies to remove water from the reaction media are proposed since water is a by-product of the process, which favors the reverse reaction (hydrolysis).

The presence of water in the reaction medium during the esterification process can be quantified by its water activity $\left(\mathrm{a}_{\mathrm{w}}\right)$, which governs the hydration of enzymes, also indicating the massive action of water [159]. Several techniques have been used to minimize the effect of $\mathrm{a}_{\mathrm{w}}$ on the esterification yield since its value constantly changes due to the continuous production of water during the course of reaction [160]. Some techniques include vacuum evaporation [161], absorption by cation exchange resins [162], pervaporation [163], and molecular sieves [164], among others. Phytosteryl ester synthesis with 
pinolenic acid using immobilized C. rugosa lipase was tested under vacuum in a pressure range between 0.7 and $100 \mathrm{kPa}$ [90]. The degree of conversion increased from $86 \mathrm{~mol} \%$ to $93 \mathrm{~mol} \%$ when the vacuum was increased (from $100 \mathrm{kPa}$ to $80 \mathrm{kPa}$ ), indicating a positive effect of water removal. However, decreasing the pressure to $13 \mathrm{kPa}$ did not lead to changes in the reaction initial rate or maximum conversion, and a further decrease in pressure reduced both these biocatalytic parameters. These results indicate that the improvements promoted by vacuum have optimal values, above which the enzyme activity decrease, possibly via limited availability of essential water for the biocatalysis.

Some studies used salt hydrate pairs to keep the water activity at a constant value, but this system is not potentially scalable [81,124]. Alternatively, the introduction of air or nitrogen into the reaction medium [165-167] has several advantages, such as the high water transfer and low effect on the enzyme activity and stability [168]. Controlling the water activity by the introduction of dry air through the reaction medium with a digital feedbackcontrolled flow rate was proposed by Cui et al. [82] for the esterification of phytosterol ester by Yarrowia lipolytica lipase Ylip2 immobilized on an inorganic support. The low water activity $(15 \%)$ resulted in a considerable improvement in phytosterol conversion $(91.1 \%)$ as well as a decreased reaction time $(78 \mathrm{~h})$.

Dong et al. [78] investigated the esterification of phytosterols with polyunsaturated fatty acid in a solvent-free system and achieved, under optimized conditions, a conversion of about $90 \%$. Apparently, their strategy to remove water from the reaction medium was to use a hydrophobic material, the hollow mesoporous silica sphere modified with octadecyl, to immobilize C. rugosa lipase. A Pickering emulsion reaction system was created by Dong et al. [115] by an immobilized C. rugosa lipase on mesoporous carbon spheres, working as both emulsifier and catalyst. Each micelle contained the reactants in the oil phase, which repealed the water, and the oil-water interface maintained the lipase "lid" in the opened position, increasing its catalytic performance. A 95\% conversion to phytosterol ester was achieved after $1.5 \mathrm{~h}$.

\subsubsection{Reaction Time}

Reaction time influences the process viability and, therefore, must be taken into account in phytosterol ester synthesis. The effect of the reaction time from 6 to $54 \mathrm{~h}$ was investigated on the esterification yield of $\beta$-sitosterol laurate and an increase from 17.88 to $70.26 \%$ was observed when the reaction time increased from 6 to $42 \mathrm{~h}$ [73].

Shang et al. [81] studied the effect of reaction time in the production of phytosterols esters using immobilized lipase and found that the conversion increased rapidly in the initial period of $4 \mathrm{~h}$, and then slowly to a maximum value (96.5\%) after $6 \mathrm{~h}$. Liu et al. [77] also evaluated the effect of reaction time in the synthesis of $\beta$-sitosterol linolenate and observed that, as the reaction time progressed, the conversion rate gradually increased and remained basically unchanged after reaching $300 \mathrm{~min}$.

\subsection{Potential Technologies for Biocatalytic Synthesis of Phytosterol Esters}

The use of some technologies in the biocatalytic synthesis of phytosterol esters can improve its performance: shorten reaction time, reduce costs, dispense the use of organic solvents, and increase conversion. Some examples are ultrasound-assisted biocatalysis, microwave irradiation, or the use of supercritical fluids.

Ultrasound is a technology that uses sound energy at frequencies above $16 \mathrm{kHz}$. The sound comprises longitudinal waves that present cycles of compression and rarefaction, which can produce a phenomenon known as cavitation [169]. This phenomenon has been used to increase the esterification rate of enzymatic reactions. The use of ultrasound is linked to the reduction of transport barriers between the enzymes and the target site, which helps to increase the enzyme-to-substrate ratio at the target site and reduce the reaction time [150]. The stabilization of the enzyme in a solution can also be improved by the application of ultrasound, as it avoids enzyme agglomeration [169]. To improve enzymatic reactions using ultrasound, the frequency employed must be adjusted because 
high intensities can cause enzyme structure disruption and low intensity may not result in the desirable cavitation effect $[170,171]$.

Zheng et al. [137] studied the production of phytosterol esters using Canadia sp. lipase under ultrasound irradiation and found that the pre-treatment by ultrasound for 8 to $10 \mathrm{~h}$ could accelerate the esterification or transesterification of the phytosterol esters, with a general conversion two times higher than the stirring process for 16 to $24 \mathrm{~h}$. The authors also reported that the treatment did not affect lipase activity.

Microwave irradiation has also been used to improve the performance of enzymatic reactions. This technology can increase the activity and thermal stability of enzymes by directly supplying energy to the reaction medium molecules (for example, solvents, substrates, catalysts), resulting in a short reaction time as well as a high yield [86]. It has been reported that microwave irradiation may enhance the non-covalent forces that maintain enzyme structure, different from conventional heating [86,172]. However, it is important to emphasize that, being a heating strategy, it can also cause protein unfolding. Therefore, controlling process conditions, especially temperature, is critical to prevent enzyme denaturation.

The synergism between microwave irradiation and enzymatic catalysis, aiming at increasing the esterification yield of phytosterol esters, has been reported. The production of oleate phytosterol using C. rugosa lipase and microwave as a heating source yielded $75.26 \%$ of esterification [88]. Shang et al. [86] used microwave irradiation to catalyze the esterification of phytosterols and oleic acid in the presence of immobilized C. rugosa lipase and observed an esterification yield of $95 \%$ with $1 \mathrm{~h}$ of reaction, whereas conventional methods would require $6 \mathrm{~h}$ to obtain the same conversion.

Recently, the use of supercritical fluids has also received attention in the production of esters by an enzymatic route. Supercritical fluids are fluids above their critical temperature and pressure, having liquid-like densities and gas-like diffusivities, characteristics that favor mass transfer in the reaction system [71]. Supercritical fluids are widely used in the food industry due to their low toxicity, low cost, and low impact on the physical and chemical properties of foods [173]. Among the supercritical fluids, carbon dioxide $\left(\mathrm{CO}_{2}\right)$ is the most common due to its advantages such as non-flammability, inertness, the possibility of full recovery at the end of the process, and moderate critical properties (Critical pressure $=7.38 \mathrm{MPa}$, Critical temperature $=304.2 \mathrm{~K})$ [173] .

There are still a few studies using supercritical fluids for the synthesis of phytosterol esters. YU et al. [76] studied the esterification of phytosterol and free fatty acids using Novozyme 435 in supercritical $\mathrm{CO}_{2}$ and found that with increasing $\mathrm{CO}_{2}$ filling pressure, the esterification reaction rate also increased, obtaining an esterification yield of $93.2 \%$.

Considering large-scale industrial phytosterol ester production, the immobilization of lipase in packed bed reactors would be most promising. In those reactors, continuous production can be achieved, and it can be reused for long periods of time [116]. The synthesis of phytosteryl ester by an immobilized commercial lipase from C. rugosa was tested in a recirculating packed bed reactor. The conversion of phytosterol with fatty acid from echium oil reached $90 \mathrm{~mol} \%$. Xiao et al. [116] tested an ultrafast continuous esterification/transesterification method based on the monolithic continuous flow bioreactor for phytosterol ester synthesis, resulting in high catalytic activity and a possible $200 \mathrm{~h}$ of continuous use without enzymatic activity loss. Most recently, a continuous-flow bioreactor packed with lipase immobilized in hollow mesoporous silicon spheres was developed for the synthesis of functional phytosterol esters, resulting in a conversion of $94 \%$ and a production of $1564 \mathrm{~g}$ phytosterol esters per $\mathrm{g}$ of catalyst in a continuous 30-day processing period [110].

\section{Analytical Methods for Phytosterol Esters' Detection: Confirming the Synthesis}

In nature, plants have a wide molecular variety of phytosterols that can be found either free or esterified to fatty acids or phenolic acids or conjugated to glycosides and 
acyl glycosidic chains [174]. The concentration of free and conjugated phytosterol esters in plants and many foods can vary considerably.

Free sterols and sterol fatty acid esters are the most common forms of phytosterols in plants. Therefore, their contents in natural sources are well known. However, conjugated sterols such as acyl glycosides, acylated steryl glycosides, and steryl ferulates have not been fully characterized as we lack dependable and comprehensive analytical methods. Therefore, their functions in plants remain poorly understood [175]. Analysis of the plant sterol profile, concomitantly addressing free and conjugated forms, is not an easy task [176]. Most frequently, the preferable approach is using a chromatographic method coupled to a mass spectrometer (MS), achieving separation of sterols and subsequent identification with a high degree of certainty, depending on the mass detector used [177]. In general, liquid chromatography (LC) has the advantage on sample preparation over gas chromatography (GC) [178]; in the former, sample extracts usually can be analyzed directly, in contrast to the latter that demands derivatization to block hydroxyls in free sterols and glucoside and phenolics' conjugates [179]. Most frequently, phytosterols and their derivatives are silylated, meaning that hydroxyl groups react with a silylation reagent, thus producing less polar and, consequently, more volatile and/or thermally resistant derivatives for GC analysis [180]. Although sample preparation for GC is time consuming and may be tricky, chromatographic peak resolution is generally higher than in LC. Besides, ionization in GC-MS occurs in the gas phase and, thus, tends to produce mass spectra that are easier to interpret and to assign peak identity [181]. Both LC-MS and GC-MS can provide highquality data of plant sterol profile in real samples, and the choice of method depends on laboratory infrastructure and on analysts' training in each laboratory [178].

A liquid chromatography-mass spectrometry (LC-MS) method in a single quadrupole mass detector was used to analyze the chemical profile of free phytosterols and esters of fatty acids, such as palmitic, stearic, oleic, linolenic, and linoleic acids in a tobacco extract with little sample preparation [182]. Phytosterol esters were separated by a non-aqueous reversed-phase chromatography technique using acetone (A) and acetonitrile (B) as mobile phase with a flow rate of $1.0 \mathrm{~mL} / \mathrm{min}$ in gradient condition: A $100 \%$ at $0 \mathrm{~min}, \mathrm{~A} 30 \%$ at $10 \mathrm{~min}, \mathrm{~A} 20 \%$ at $30 \mathrm{~min}, \mathrm{~A} 0 \%$ at $40 \mathrm{~min}$, and A $\%$ (B 100\%) until $55 \mathrm{~min}$. The analytes were ionized in an atmospheric pressure chemical ionization ion source, and more than 20 compounds were identified. The complete separation of phytosterols and phytosterol esters was performed, including the higher fatty acids such as palmitic acid (C16), stearic acid (C18), oleic acid (C18:1), linoleic acid (C18:2), and linolenic acid (C18:3) without preliminary separation and quantified based on authentic standards.

Free and conjugated phytosterols' profile in rice bran and its oil were determined by high-temperature GC-MS (HTGC-MS), combined with the method of a single standard to determine multi-components to provide qualitative and quantitative data on free sterols and steryl glycosides [183]. To achieve a more comprehensive chemical profile, steryl ferulates were determined by high-performance liquid chromatography with a photondiode array detector (HPLC-PDA). The authors claimed to have reduced laborious sample pre-treatment and native analytes' losses, improving overall data quality and quantification accuracy.

Analysis of phytosterol esters is a subject of continuous interest, and, therefore, effective methods of separation and quantification are continually being developed and published. Recently, an innovative method was developed for phytosterol derivatization to improve HPLC-PDA analysis and ESI-MS detection for analysis of plant sterols and stanols [184]. This derivatization method aims at improving the detection of these esters in the LC chromatographic techniques by reducing lipophilicity and attaching a chromophore group. The highest yields of phytosterol derivatives were obtained with $8 \mathrm{mg} \mathrm{ml}^{-1}$ of 4-dimethylaminopyridine (DMAP) and dichloromethane as reaction medium. The proposed modified derivatization method presented high reproducibility $(\mathrm{RSD}=1.2-2.7 \%)$ and good linearity $\left(\mathrm{R}^{2}=0.9982-0.9999\right)$. Additionally, this derivatization allowed the use of detection wavelengths with higher values that were more selective. The derivatives 
had higher absorptivity and, thus, higher signal/noise ratios. The method seemed to have improved the chromatographic separation of phytosterols.

\section{Technology Challenges and Safety of Sterol Esters}

The most used process to synthesize phytosterol esters is based on chemical esterification, which occurs at high temperatures (high-energy demanding process), generates considerable amounts of by-products, and presents low selectivity. In this context, biocatalysis represents an environmentally friendlier route for the synthesis of these compounds, especially for the food sector. Enzymatic catalysis is highly advantageous to produce such esters as the only reaction products and without toxic reagents, providing industrial inputs with better quality and safer for use in food products.

The present review showed many promising data of the use of lipases in direct esterification and transesterification reactions to obtain phytosterol esters, showing high conversions rates and reduced reaction times, comparable to those obtained by chemical synthesis. However, most data come from works that have been limited to the use of some specific lipases, and, in many cases, the enzymes were tested in their free form.

Future studies of biocatalysis for phytosterol ester synthesis should consider testing low-cost enzymes, for example, those produced from agro-industrial wastes $[38,40,41]$, and to investigate immobilized biocatalysts to facilitate their recovery and reuse. Enzyme immobilization on hydrophobic supports is of greatest interest, as the reaction medium needs to be in a low-water environment to restrict hydrolysis reactions. Continuous flow bioreactors with the enzyme immobilized in hydrophobic supports must be considered for possible industrial applications, as already demonstrated by Xiao et al. [116] and $\mathrm{Xu}$ et al. [110]. Ultrasound and microwave irradiation are potentially useful strategies to accelerate enzymatic reactions so they can be competitive in relation to chemical processes, as proven by Zheng et al. [137] and Shang et al. [86], respectively.

A further challenge of this technology is the need for a non-aqueous medium, which usually requires an organic solvent, reducing the process environmental friendliness. The solvent is important in the reactions to produce phytosterol esters, as, in addition to contributing to the removal of water on the enzyme surface, it also increases the solubility of the phytosterols, which is essential for obtaining a high yield of esterification. For these reasons, few investigations have been conducted on solvent-free media with satisfactory results, and, therefore, new alternatives must be tested to increase yield. Compared to organic solvents, supercritical fluid can be considered a solvent-free system and can be used in the food industry because of low toxicity. This strategy has been tested for phytosterol ester synthesis catalyzed by lipase with success [76]. Recently, a simple mathematical tool called Substrate-Enzyme Relation (SER) was developed by de Sousa et al. [185] to conciliate the thermodynamics' and kinetics' aspects towards high conversions in enzymatic ester synthesis, indicating a range of reaction conditions to accomplish that. As for the enzyme, strategies to limit water availability in the catalytic site are potential technologies, for example, immobilization in highly hydrophobic supports $[78,115]$ or the modification of its surface by direct evolution technology, which have been performed for other purposes with great success, as reviewed by Bornscheuer and Pohl [28].

Author Contributions: Conceptualization, A.d.S.P., A.G.T. and P.F.F.A.; validation, A.d.S.P., A.H.d.S. and J.L.F.; formal analysis, A.d.S.P., J.L.F. and P.F.F.A.; investigation, A.d.S.P., A.H.d.S. and J.L.F.; resources, A.d.S.P., A.H.d.S., J.L.F., A.G.T. and P.F.F.A.; writing-original draft preparation, A.d.S.P., J.L.F., A.H.d.S., A.G.T. and P.F.F.A.; writing—review and editing, A.d.S.P., A.G.T., P.F.F.A. and P.V.; visualization, A.d.S.P., A.G.T. and P.F.F.A.; supervision, A.G.T., P.F.F.A. and P.V.; project administration, P.F.F.A.; funding acquisition, A.d.S.P., J.L.F., A.G.T. and P.F.F.A. All authors have read and agreed to the published version of the manuscript. 
Funding: This research was funded (Brazil) by Carlos Chagas Filho Foundation for Research Support of the State of Rio de Janeiro (Grant numbers: E-26/201.915/2020 Bolsa, E-26/202.023/2020 Bolsa, and E-26/201.161/2021 Bolsa), Coordination for the Improvement of Higher Education Personnel (MSc studentship for A.S. and Finance Code 001), and National Council for Scientific and Technological Development (Grant numbers 308626/2019-2 and 432484/2016-7).

Data Availability Statement: All data presented in this work, including the lists and spreadsheets of papers and patents retrieved in our searches, will be provided by the authors upon request.

Conflicts of Interest: The authors declare no conflict of interest. The funders had no role in the design of the study; in the collection, analyses, or interpretation of data; in the writing of the manuscript or in the decision to publish the results.

\section{References}

1. Daels, E.; Foubert, I.; Goderis, B. The effect of adding a commercial phytosterol ester mixture on the phase behavior of palm oil. Food Res. Int. 2017, 100, 841-849. [CrossRef] [PubMed]

2. Lagarda, M.J.; García-Llatas, G.; Farré, R. Analysis of phytosterols in foods. J. Pharm. Biomed. Anal. 2006, 41, 1486-1496. [CrossRef] [PubMed]

3. da Costa, P.A.; Ballus, C.A.; Teixeira-Filho, J.; Godoy, H.T. Phytosterols and tocopherols content of pulps and nuts of Brazilian fruits. Food Res. Int. 2010, 43, 1603-1606. [CrossRef]

4. Santos, R.; Limas, E.; Sousa, M.; da Conceição Castilho, M.; Ramos, F.; da Silveira, M.I.N. Optimization of analytical procedures for GC-MS determination of phytosterols and phytostanols in enriched milk and yoghurt. Food Chem. 2007, 102, 113-117. [CrossRef]

5. Pennisi Forell, S.C.; Ranalli, N.; Zaritzky, N.E.; Andrés, S.C.; Califano, A.N. Effect of type of emulsifiers and antioxidants on oxidative stability, colour and fatty acid profile of low-fat beef burgers enriched with unsaturated fatty acids and phytosterols. Meat Sci. 2010, 86, 364-370. [CrossRef]

6. Brufau, G.; Canela, M.A.; Rafecas, M. Phytosterols: Physiologic and metabolic aspects related to cholesterol-lowering properties. Nutr. Res. 2008, 28, 217-225. [CrossRef]

7. Toivo, J.; Phillips, K.; Lampi, A.M.; Piironen, V. Determination of sterols in foods: Recovery of free, esterified, and glycosidic sterols. J. Food Compos. Anal. 2001, 14, 631-643. [CrossRef]

8. Mel'nikov, S.M.; Seijen Ten Hoorn, J.W.M.; Eijkelenboom, A.P.A.M. Effect of phytosterols and phytostanols on the solubilization of cholesterol by dietary mixed micelles: An in vitro study. Chem. Phys. Lipids 2004, 127, 121-141. [CrossRef]

9. Rozner, S.; Popov, I.; Uvarov, V.; Aserin, A.; Garti, N. Templated cocrystallization of cholesterol and phytosterols from microemulsions. J. Cryst. Growth 2009, 311, 4022-4033. [CrossRef]

10. Binder, T.P.; Gottemoller, T.V. Hydrothermically Processed Compositions Containing Phytosterols. U.S. Patent Application 10/410,193, 22 January 2004.

11. Di Battista, C.A.; Ramírez-Rigo, M.V.; Piña, J. Microencapsulation of Phytosterols by Spray Drying. In Studies in Natural Products Chemistry; Elsevier B.V.: Amsterdam, The Netherlands, 2018; Volume 56, pp. 437-468.

12. Plat, J.; Baumgartner, S.; Vanmierlo, T.; Lütjohann, D.; Calkins, K.L.; Burrin, D.G.; Guthrie, G.; Thijs, C.; Te Velde, A.A.; Vreugdenhil, A.C.E.; et al. Plant-based sterols and stanols in health \& disease: "Consequences of human development in a plant-based environment?". Prog. Lipid Res. 2019, 74, 87-102. [CrossRef]

13. Yang, F.; Oyeyinka, S.A.; Ma, Y. Novel Synthesis of Phytosterol Ester from Soybean Sterol and Acetic Anhydride. J. Food Sci. 2016, 81, C1629-C1635. [CrossRef]

14. Wester, I. Cholesterol-lowering effect of plant sterols. Eur. J. Lipid Sci. Technol. 2000, 102, 37-44. [CrossRef]

15. Tan, Z.; Shahidi, F. Optimization of enzymatic synthesis of phytosteryl caprylates using response surface methodology. JAOCS J. Am. Oil Chem. Soc. 2012, 89, 657-666. [CrossRef]

16. He, W.S.; Li, L.L.; Huang, Q.J.; Yin, J.; Cao, X.C. Highly efficient synthesis of phytosterol linolenate in the presence of Bronsted acidic ionic liquid. Food Chem. 2018, 263, 1-7. [CrossRef]

17. Yang, F.; Oyeyinka, S.A.; Xu, W.; Ma, Y.; Zhou, S. In vitro bioaccessibility and physicochemical properties of phytosterol linoleic ester synthesized from soybean sterol and linoleic acid. LWT-Food Sci. Technol. 2018, 92, 265-271. [CrossRef]

18. Mussner, M.J.; Parhofer, K.G.; Von Bergmann, K.; Schwandt, P.; Broedl, U.; Otto, C. Effects of phytosterol ester-enriched margarine on plasma lipoproteins in mild to moderate hypercholesterolemia are related to basal cholesterol and fat intake. Metabolism 2002, 51, 189-194. [CrossRef]

19. Davidson, M.H.; Maki, K.C.; Umporowicz, D.M.; Ingram, K.A.; Dicklin, M.R.; Lane, R.W.; Franke, W.C.; Robins, S.J.; Schaefer, E.; McNamara, J.R.; et al. Safety and tolerability of esterified phytosterols administered in reduced-fat spread and salad dressing to healthy adult men and women. J. Am. Coll. Nutr. 2001, 20, 307-319. [CrossRef]

20. Kwak, H.S.; Ahn, H.J.; Ahn, J. Development of phytosterol ester-added Cheddar cheese for lowering blood cholesterol. AsianAustralas. J. Anim. Sci. 2005, 18, 267-276. [CrossRef]

21. Meng, X.; Sun, P.; Pan, Q.; Shi, Z.; Yang, K.; He, R. Synthesis of plant sterol esters catalyzed by heteropolyacid in a solvent-free system. Eur. J. Lipid Sci. Technol. 2006, 108, 13-18. [CrossRef] 
22. Pouilloux, Y.; Courtois, G.; Boisseau, M.; Piccirilli, A.; Barrault, J. Solid base catalysts for the synthesis of phytosterol esters. Green Chem. 2003, 5, 89-91. [CrossRef]

23. Nguyen, H.C.; Huang, K.C.; Su, C.H. Green process for the preparation of phytosterol esters: Microwave-mediated noncatalytic synthesis. Chem. Eng. J. 2020, 382, 122796. [CrossRef]

24. He, Y.; Li, J.; Kodali, S.; Balle, T.; Chen, B.; Guo, Z. Liquid lipases for enzymatic concentration of n-3 polyunsaturated fatty acids in monoacylglycerols via ethanolysis: Catalytic specificity and parameterization. Bioresour. Technol. 2017, 224, 445-456. [CrossRef] [PubMed]

25. Singh, R.; Kumar, M.; Mittal, A.; Mehta, P.K. Microbial enzymes: Industrial progress in 21st century. 3 Biotech 2016, 6, 174. [CrossRef] [PubMed]

26. Brígida, A.I.S.; Amaral, P.F.F.; Coelho, M.A.Z.; Gonçalves, L.R.B. Lipase from Yarrowia lipolytica: Production, characterization and application as an industrial biocatalyst. J. Mol. Catal. B Enzym. 2014, 101, 148-158. [CrossRef]

27. Akil, E.; Pereira, A.d.S.; El-Bacha, T.; Amaral, P.F.F.; Torres, A.G. Efficient production of bioactive structured lipids by fast acidolysis catalyzed by Yarrowia lipolytica lipase, free and immobilized in chitosan-alginate beads, in solvent-free medium. Int. J. Biol. Macromol. 2020, 163, 910-918. [CrossRef] [PubMed]

28. Bornscheuer, U.T.; Pohl, M. Improved biocatalysts by directed evolution and rational protein design. Curr. Opin. Chem. Biol. 2001, 5, 137-143. [CrossRef]

29. Ortiz, C.; Ferreira, M.L.; Barbosa, O.; Dos Santos, J.C.S.; Rodrigues, R.C.; Berenguer-Murcia, Á.; Briand, L.E.; Fernandez-Lafuente, R. Novozym 435: The "perfect" lipase immobilized biocatalyst? Catal. Sci. Technol. 2019, 9, 2380-2420. [CrossRef]

30. Fraga, J.L.; Penha, A.C.B.; Pereira, A.d.S.; Silva, K.A.; Akil, E.; Torres, A.G.; Amaral, P.F.F. Use of Yarrowia lipolytica Lipase Immobilized in Cell Debris for the Production of Lipolyzed Milk Fat (LMF). Int. J. Mol. Sci. 2018, 19, 3413. [CrossRef]

31. Vilas Bôas, R.N.; Ceron, A.A.; Bento, H.B.S.; de Castro, H.F. Application of an immobilized Rhizopus oryzae lipase to batch and continuous ester synthesis with a mixture of a lauric acid and fusel oil. Biomass Bioenergy 2018, 119, 61-68. [CrossRef]

32. Yang, T.; Fruekilde, M.B.; Xu, X. Applications of Immobilized Thermomyces Ianuginosa Lipase in Interesterification. JAOCS J. Am. Oil Chem. Soc. 2003, 80, 881-887. [CrossRef]

33. Lv, L.; Dai, L.; Du, W.; Liu, D. Effect of water on lipase NS81006-catalyzed alcoholysis for biodiesel production. Process Biochem. 2017, 58, 239-244. [CrossRef]

34. Zeng, S.; Liu, J.; Anankanbil, S.; Chen, M.; Guo, Z.; Adams, J.P.; Snajdrova, R.; Li, Z. Amide Synthesis via Aminolysis of Ester or Acid with an Intracellular Lipase. ACS Catal. 2018, 8, 8856-8865. [CrossRef]

35. Rajendran, A.; Palanisamy, A.; Thangavelu, V. Lipase catalyzed ester synthesis for food processing industries. Braz. Arch. Biol. Technol. 2009, 52, 207-219. [CrossRef]

36. Casas-Godoy, L.; Gasteazoro, F.; Duquesne, S.; Bordes, F.; Marty, A.; Sandoval, G. Lipases: An Overview. Methods Mol. Biol. 2018, 1835, 3-38. [CrossRef]

37. Nguyen, H.H.; Kim, M. An Overview of Techniques in Enzyme Immobilization. Appl. Sci. Converg. Technol. 2017, 26, 157-163. [CrossRef]

38. Pereira, A.d.S.; Fontes-Sant'Ana, G.C.; Amaral, P.F.F. Mango agro-industrial wastes for lipase production from Yarrowia lipolytica and the potential of the fermented solid as a biocatalyst. Food Bioprod. Process. 2019, 115, 68-77. [CrossRef]

39. He, Y.Q.; Tan, T.W. Use of response surface methodology to optimize culture medium for production of lipase with Candida sp. 99-125. J. Mol. Catal. B Enzym. 2006, 43, 9-14. [CrossRef]

40. Fraga, J.L.; Souza, C.P.L.; Pereira, A.d.S.; Aguieiras, E.C.G.; de Silva, L.O.; Torres, A.G.; Freire, D.G.; Amaral, P.F.F. Palm oil wastes as feedstock for lipase production by Yarrowia lipolytica and biocatalyst application/reuse. 3 Biotech 2021, 11, 191. [CrossRef]

41. Nunes, P.M.B.; Fraga, J.L.; Ratier, R.B.; Rocha-Leão, M.H.M.; Brígida, A.I.S.; Fickers, P.; Amaral, P.F.F. Waste soybean frying oil for the production, extraction, and characterization of cell-wall-associated lipases from Yarrowia lipolytica. Bioprocess Biosyst. Eng. 2021, 44, 809-818. [CrossRef]

42. Pereira, A.d.S.; Diniz, M.M.; De Jong, G.; Gama Filho, H.S.; dos Anjos, M.J.; Finotelli, P.V.; Fontes-Sant'Ana, G.C.; Amaral, P.F.F. Chitosan-alginate beads as encapsulating agents for Yarrowia lipolytica lipase: Morphological, physico-chemical and kinetic characteristics. Int. J. Biol. Macromol. 2019, 139, 621-630. [CrossRef]

43. Pereira, A.d.S.; Fraga, J.L.; Diniz, M.M.; Fontes-Sant'ana, G.C.; Amaral, P.F.F. High catalytic activity of lipase from Yarrowia lipolytica immobilized by microencapsulation. Int. J. Mol. Sci. 2018, 19, 3393. [CrossRef] [PubMed]

44. Tran, D.N.; Balkus, K.J. Perspective of recent progress in immobilization of enzymes. ACS Catal. 2011, 1, 956-968. [CrossRef]

45. Carvalho, T.; Pereira, A.d.S.; Bonomo, R.C.F.; Franco, M.; Finotelli, P.V.; Amaral, P.F.F. Simple physical adsorption technique to immobilize Yarrowia lipolytica lipase purified by different methods on magnetic nanoparticles: Adsorption isotherms and thermodynamic approach. Int. J. Biol. Macromol. 2020, 160, 889-902. [CrossRef] [PubMed]

46. Kapoor, M.; Gupta, M.N. Lipase promiscuity and its biochemical applications. Process Biochem. 2012, 47, 555-569. [CrossRef]

47. Lenfant, N.; Hotelier, T.; Velluet, E.; Bourne, Y.; Marchot, P.; Chatonnet, A. ESTHER, the database of the $\alpha / \beta$-hydrolase fold superfamily of proteins: Tools to explore diversity of functions. Nucleic Acids Res. 2013, 41, D423-D429. [CrossRef]

48. Anobom, C.D.; Pinheiro, A.S.; De-Andrade, R.A.; Aguieiras, E.C.G.; Andrade, G.C.; Moura, M.V.; Almeida, R.V.; Freire, D.M. From structure to catalysis: Recent developments in the biotechnological applications of lipases. BioMed Res. Int. 2014, $2014,684506$. [CrossRef] 
49. Gupta, R.; Kumari, A.; Syal, P.; Singh, Y. Molecular and functional diversity of yeast and fungal lipases: Their role in biotechnology and cellular physiology. Prog. Lipid Res. 2015, 57, 40-54. [CrossRef]

50. Pleiss, J.; Fischer, M.; Schmid, R.D. Anatomy of lipase binding sites: The scissile fatty acid binding site. Chem. Phys. Lipids 1998, 93, 67-80. [CrossRef]

51. De Almeida, J.M.; Moure, V.R.; Müller-Santos, M.; De Souza, E.M.; Pedrosa, F.O.; Mitchell, D.A.; Krieger, N. Tailoring recombinant lipases: Keeping the His-tag favors esterification reactions, removing it favors hydrolysis reactions. Sci. Rep. 2018, $8,10000$. [CrossRef]

52. Cen, Y.; Singh, W.; Arkin, M.; Moody, T.S.; Huang, M.; Zhou, J.; Wu, Q.; Reetz, M.T. Artificial cysteine-lipases with high activity and altered catalytic mechanism created by laboratory evolution. Nat. Commun. 2019, 10, 3198. [CrossRef]

53. Bornscheuer, U.T.; Huisman, G.W.; Kazlauskas, R.J.; Lutz, S.; Moore, J.C.; Robins, K. Engineering the third wave of biocatalysis. Nature 2012, 485, 185-194. [CrossRef]

54. Bassegoda, A.; Cesarini, S.; Diaz, P. Lipase improvement: Goals and strategies. Comput. Struct. Biotechnol. J. 2012 , 2, e201209005. [CrossRef]

55. Quin, M.B.; Schmidt-Dannert, C. Engineering of biocatalysts: From evolution to creation. ACS Catal. 2011, 1, 1017-1021. [CrossRef]

56. Zhang, N.; Suen, W.C.; Windsor, W.; Xiao, L.; Madison, V.; Zaks, A. Improving tolerance of Candida antarctica lipase B towards irreversible thermal inactivation through directed evolution. Protein Eng. 2003, 16, 599-605. [CrossRef]

57. Elgharbawy, A.A.; Riyadi, F.A.; Alam, M.Z.; Moniruzzaman, M. Ionic liquids as a potential solvent for lipase-catalysed reactions: A review. J. Mol. Liq. 2018, 251, 150-166. [CrossRef]

58. Duhan, N.; Barak, S.; Mudgil, D. Bioactive lipids: Chemistry \& health benefits. Biointerface Res. Appl. Chem. 2020, 10, 6676-6687. [CrossRef]

59. Chiurchiù, V.; Leuti, A.; Maccarrone, M. Bioactive lipids and chronic inflammation: Managing the fire within. Front. Immunol. 2018, 9, 38. [CrossRef]

60. Bari, M.; Bisogno, T.; Battista, N. Bioactive lipids in health and disease. Biomolecules 2020, 10, 1698. [CrossRef]

61. O'Shea, M.; Bassaganya-Riera, J.; Mohede, I.C.M. Immunomodulatory properties of conjugated linoleic acid. Am. J. Clin. Nutr. 2004, 79, 1199-1206. [CrossRef]

62. Moreau, R.A.; Nyström, L.; Whitaker, B.D.; Winkler-Moser, J.K.; Baer, D.J.; Gebauer, S.K.; Hicks, K.B. Phytosterols and their derivatives: Structural diversity, distribution, metabolism, analysis, and health-promoting uses. Prog. Lipid Res. 2018, 70, 35-61. [CrossRef]

63. Ogbe, R.J.; Ochalefu, D.O.; Mafulul, S.G.; Olaniru, O.B. A review on dietary phytosterols: Their occurrence, metabolism and health benefits. Pelagia Res. Libr. Asian J. Plant Sci. Res. 2015, 5, 10-21.

64. Granato, D.; Barba, F.J.; Bursać Kovačević, D.; Lorenzo, J.M.; Cruz, A.G.; Putnik, P. Functional Foods: Product Development, Technological Trends, Efficacy Testing, and Safety. Annu. Rev. Food Sci. Technol. 2020, 11, 93-118. [CrossRef] [PubMed]

65. He, W.S.; Cui, D.D.; Zhang, Y.L.; Liu, Y.; Yin, J.; Chen, G.; Jia, C.S.; Feng, B. Highly efficient synthesis of phytosterol linolenate catalyzed by Candida rugosa lipase through transesterification. Food Sci. Technol. Res. 2017, 23, 525-533. [CrossRef]

66. Akashe, A.; Miller, M. Use of Mesophase-Stabilized Compositions for Delivery of Cholesterol-Reducing Sterols and Stanols in Food Products. U.S. Patent 6,274,574, 14 August 2001.

67. He, W.S.; Zhu, H.; Chen, Z.Y. Plant Sterols: Chemical and Enzymatic Structural Modifications and Effects on Their CholesterolLowering Activity. J. Agric. Food Chem. 2018, 66, 3047-3062. [CrossRef]

68. Meng, X.; Pan, Q.; Yang, T. Synthesis of phytosteryl esters by using alumina-supported zinc oxide $\left(\mathrm{ZnO} / \mathrm{Al}_{2} \mathrm{O}_{3}\right)$ from esterification production of phytosterol with fatty acid. JAOCS J. Am. Oil Chem. Soc. 2011, 88, 143-149. [CrossRef]

69. He, B.; Deng, T.; Li, J.; Yan, F.; Wang, H.; Huang, Y.; Peng, C. An innovative auto-catalytic esterification for the production of phytosterol esters: Experiment and kinetics. RSC Adv. 2014, 4, 64319-64327. [CrossRef]

70. Saroja, M.; Kaimal, T.N.B. A convenient method of esterification of fatty acids. Preparation of alkyl esters, sterol esters, wax esters and triacylglycerols. Synth. Commun. 1986, 16, 1423-1430. [CrossRef]

71. SÁ, A.G.A.; de Meneses, A.C.; de Araújo, P.H.H.; de Oliveira, D. A review on enzymatic synthesis of aromatic esters used as flavor ingredients for food, cosmetics and pharmaceuticals industries. Trends Food Sci. Technol. 2017, 69, 95-105. [CrossRef]

72. Ansorge-Schumacher, M.B.; Thum, O. Immobilised lipases in the cosmetics industry. Chem. Soc. Rev. 2013, 42, 6475-6490. [CrossRef]

73. Chen, S.; Li, J.; Fu, Z.; Wei, G.; Li, H.; Zhang, B.; Zheng, L.; Deng, Z. Enzymatic Synthesis of $\beta$-Sitosterol Laurate by Candida rugosa Lipase AY30 in the Water/AOT/Isooctane Reverse Micelle. Appl. Biochem. Biotechnol. 2020, 192, 392-414. [CrossRef]

74. Yao, G.; Wang, X.; Yang, M.; Chen, F.; Ling, Y.; Liu, T.; Xing, S.; Yao, M.; Zhang, F. Co-immobilization of bi-lipases on magnetic nanoparticles as an efficient catalyst for synthesis of functional oil rich in diacylglycerols, phytosterol esters and $\alpha$-linolenic acid. LWT 2020, 129, 109522. [CrossRef]

75. Chang, M.; Zhang, T.; Feng, W.; Wang, T.; Liu, R.; Jin, Q.; Wang, X. Preparation of highly pure stigmasteryl oleate by enzymatic esterification of stigmasterol enriched from soybean phytosterols. LWT 2020, 128, 109464. [CrossRef]

76. Yu, D.; Wang, T.; Chen, J.; Tang, H.; Li, D.; Zhang, X.; Geng, H.; Wang, L.; Elfalleh, W.; Jiang, L. Enzymatic esterification of rice bran oil and phytosterol in supercritical $\mathrm{CO}_{2}$. J. Food Process. Preserv. 2019, 43, e14066. [CrossRef]

77. Liu, X.; Wang, L.; Liu, P.; An, N.; Chen, G.; Zhao, R.; Hang, Z. Catalytic synthesis of $\beta$-sitosterol linolenate by Pickering emulsion-immobilized lipase. In E3S Web of Conferences; EDP Sciences: Ulis, France, 2019; Volume 78, p. 02019. [CrossRef] 
78. Dong, Z.; Jiang, M.Y.; Shi, J.; Zheng, M.M.; Huang, F.H. Preparation of immobilized lipase based on hollow mesoporous silica spheres and its application in ester synthesis. Molecules 2019, 24, 395. [CrossRef]

79. Yu, D.; Zhang, X.; Zou, D.; Wang, T.; Liu, T.; Wang, L.; Elfalleh, W.; Jiang, L. Immobilized CALB Catalyzed Transesterification of Soybean Oil and Phytosterol. Food Biophys. 2018, 13, 208-215. [CrossRef]

80. Choi, N.; Cho, H.J.; Kim, H.; Kim, Y.; Kim, H.R.; Kim, I.H. Preparation of phytosteryl ester and simultaneous enrichment of stearidonic acid via lipase-catalyzed esterification. Process Biochem. 2017, 61, 88-94. [CrossRef]

81. Shang, C.Y.; Li, W.X.; Zhang, R.F. Immobilization of Candida rugosa lipase on ZnO nanowires/macroporous silica composites for biocatalytic synthesis of phytosterol esters. Mater. Res. Bull. 2015, 68, 336-342. [CrossRef]

82. Cui, C.; Guan, N.; Xing, C.; Chen, B.; Tan, T. Immobilization of Yarrowia lipolytica lipase Ylip2 for the biocatalytic synthesis of phytosterol ester in a water activity controlled reactor. Colloids Surfaces B Biointerfaces 2016, 146, 490-497. [CrossRef]

83. Zhang, X.; Yu, J.; Zeng, A. Optimization and modeling for the synthesis of sterol esters from deodorizer distillate by lipasecatalyzed esterification. Biotechnol. Appl. Biochem. 2017, 64, 270-278. [CrossRef]

84. Choi, N.; Kim, H.; Kim, B.H.; Lee, J.; Kim, I.H. Production of phytosteryl ester from echium oil in a recirculating packed bed reactor using an immobilized lipase. J. Oleo Sci. 2017, 66, 1329-1335. [CrossRef]

85. Zeng, C.; Qi, S.; Li, Z.; Luo, R.; Yang, B.; Wang, Y. Enzymatic synthesis of phytosterol esters catalyzed by Candida rugosa lipase in water-in-[Bmim]PF6 microemulsion. Bioprocess Biosyst. Eng. 2015, 38, 939-946. [CrossRef] [PubMed]

86. Shang, C.Y.; Li, W.X.; Jiang, F.; Zhang, R.F. Improved enzymatic properties of Candida rugosa lipase immobilized on ZnO nanowires/macroporous $\mathrm{SiO}_{2}$ microwave absorbing supports. J. Mol. Catal. B Enzym. 2015, 113, 9-13. [CrossRef]

87. Zheng, M.M.; Huang, Q.; Huang, F.H.; Guo, P.M.; Xiang, X.; Deng, Q.C.; Li, W.L.; Wan, C.Y.; Zheng, C. Production of novel "functional oil" rich in diglycerides and phytosterol esters with "one-pot" enzymatic transesterification. J. Agric. Food Chem. 2014, 62, 5142-5148. [CrossRef] [PubMed]

88. Pan, L.; Liao, J.; Jiang, S.; Zuo, Y. Lipase-catalyed synthesis phytosterol oleic acid ester by microwave. J. Chin. Cereal. Oils Assoc. 2014, 29, 95-100.

89. Kobayashi, T.; Ogino, A.; Miyake, Y.; Mori, H.; Hosoda, A.; Fujita, M.; Tsuno, T.; Adachi, S. Lipase-catalyzed esterification of triterpene alcohols and phytosterols with oleic acid. JAOCS J. Am. Oil Chem. Soc. 2014, 91, 1885-1890. [CrossRef]

90. No, D.S.; Zhao, T.; Lee, J.; Lee, J.S.; Kim, I.H. Synthesis of phytosteryl ester containing pinolenic acid in a solvent-free system using immobilized Candida rugosa lipase. J. Agric. Food Chem. 2013, 61, 8934-8940. [CrossRef]

91. Panpipat, W.; Xu, X.; Guo, Z. Improved acylation of phytosterols catalyzed by Candida antarctica lipase A with superior catalytic activity. Biochem. Eng. J. 2013, 70, 55-62. [CrossRef]

92. Zheng, M.M.; Lu, Y.; Huang, F.H.; Wang, L.; Guo, P.M.; Feng, Y.Q.; Deng, Q.C. Lipase immobilization on hyper-cross-linked polymer-coated silica for biocatalytic synthesis of phytosterol esters with controllable fatty acid composition. J. Agric. Food Chem. 2013, 61, 231-237. [CrossRef]

93. Jiang, Z.; Yu, M.; Ren, L.; Zhou, H.; Wei, P. Synthesis of phytosterol esters catalyzed by immobilized lipase in organic media. Cuihua Xuebao/Chin. J. Catal. 2013, 34, 2255-2262. [CrossRef]

94. Pan, X.; Chen, B.; Wang, J.; Zhang, X.; Zhul, B.; Tan, T. Enzymatic synthesizing of phytosterol oleic esters. Appl. Biochem. Biotechnol. 2012, 168, 68-77. [CrossRef]

95. Zheng, M.M.; Lu, Y.; Dong, L.; Guo, P.M.; Deng, Q.C.; Li, W.L.; Feng, Y.Q.; Huang, F.H. Immobilization of Candida rugosa lipase on hydrophobic/strong cation-exchange functional silica particles for biocatalytic synthesis of phytosterol esters. Bioresour. Technol. 2012, 115, 141-146. [CrossRef]

96. Torrelo, G.; Torres, C.F.; Reglero, G. Enzymatic strategies for solvent-free production of short and medium chain phytosteryl esters. Eur. J. Lipid Sci. Technol. 2012, 114, 670-676. [CrossRef]

97. Tan, Z.; Shahidi, F. A novel chemoenzymatic synthesis of phytosteryl caffeates and assessment of their antioxidant activity. Food Chem. 2012, 133, 1427-1434. [CrossRef]

98. Zheng, M.M.; Dong, L.; Lu, Y.; Guo, P.M.; Deng, Q.C.; Li, W.L.; Feng, Y.Q.; Huang, F.H. Immobilization of Candida rugosa lipase on magnetic poly(allyl glycidyl ether-co-ethylene glycol dimethacrylate) polymer microsphere for synthesis of phytosterol esters of unsaturated fatty acids. J. Mol. Catal. B Enzym. 2012, 74, 16-23. [CrossRef]

99. Fauré, N.; Illanes, A. Immobilization of Pseudomonas stutzeri lipase for the transesterification of wood sterols with fatty acid esters. Appl. Biochem. Biotechnol. 2011, 165, 1332-1341. [CrossRef]

100. Hellner, G.; Toke, E.R.; Nagy, V.; Szakács, G.; Poppe, L. Integrated enzymatic production of specific structured lipid and phytosterol ester compositions. Process Biochem. 2010, 45, 1245-1250. [CrossRef]

101. Sengupta, A.; Pal, M.; Silroy, S.; Ghosh, M. Comparative study of sterol ester synthesis using thermomyces lanuginosus lipase in stirred tank and packed-bed bioreactors. JAOCS J. Am. Oil Chem. Soc. 2010, 87, 1019-1025. [CrossRef]

102. Torres, C.F.; Torrelo, G.; Vazquez, L.; Señorans, F.J.; Reglero, G. Stepwise Esterification of Phytosterols with Conjugated Linoleic Acid Catalyzed by Candida rugosa Lipase in Solvent-free Medium. J. Biosci. Bioeng. 2008, 106, 559-562. [CrossRef]

103. Torrelo, G.; Torres, C.F.; Señorans, F.J.; Blanco, R.M.; Reglero, G. Solvent-free preparation of phytosteryl esters with fatty acids from butterfat in equimolecular conditions in the presence of a lipase from Candida rugosa. J. Chem. Technol. Biotechnol. 2009, 84, 745-750. [CrossRef]

104. Kim, B.H.; Akoh, C.C. Modeling and optimization of lipase-catalyzed synthesis of phytosteryl esters of oleic acid by response surface methodology. Food Chem. 2007, 102, 336-342. [CrossRef] 
105. Villeneuve, P.; Turon, F.; Caro, Y.; Escoffier, R.; Baréa, B.; Barouh, B.; Lago, R.; Piombo, G.; Pina, M. Lipase-catalyzed synthesis of canola phytosterols oleate esters as cholesterol lowering agents. Enzyme Microb. Technol. 2005, 37, 150-155. [CrossRef]

106. Vu, P.L.; Shin, J.A.; Lim, C.H.; Lee, K.T. Lipase-catalyzed production of phytosteryl esters and their crystallization behavior in corn oil. Food Res. Int. 2004, 37, 175-180. [CrossRef]

107. Negishi, S.; Hidaka, I.; Takahashi, I.; Kunita, S. Transesterification of Phytosterol and Edible Oil by Lipase Powder at High Temperature. JAOCS J. Am. Oil Chem. Soc. 2003, 80, 905-907. [CrossRef]

108. Raja Rajan, R.G.; Gopala Krishna, A.G. A Simple Process for the Enzymatic Synthesis of Phytosterol Esters of Alpha-Linolenic Acid. Eur. J. Lipid Sci. Technol. 2014, 46, 131-137.

109. Torres, C.F.; Torrelo, G.; Señorans, F.J.; Reglero, G. A two steps enzymatic procedure to obtain sterol esters, tocopherols and fatty acid ethyl esters from soybean oil deodorizer distillate. Process Biochem. 2007, 42, 1335-1341. [CrossRef]

110. Xu, L.; Wang, J.; Huang, F.; Zheng, M. An efficient and robust continuous-flow bioreactor for the enzymatic preparation of phytosterol esters based on hollow lipase microarray. Food Chem. 2022, 372, 131256. [CrossRef] [PubMed]

111. Park, S.H.; Kim, H.K. Antibacterial activity of emulsions containing unsaturated fatty acid ergosterol esters synthesized by lipase-mediated transesterification. Enzyme Microb. Technol. 2020, 139, 109581. [CrossRef] [PubMed]

112. Wang, T.Y.; Wang, M.Y.; Song, Y.Q.; Hu, L.Z.; Yu, D.Y. Applying Response Surface Methodology to Optimize the Lipase-catalyzed Synthesis of Phytosterol Ester. Food Sci. 2011, 32, 59. [CrossRef]

113. Liu, H.-L.; Miao, M.; Jiang, B.; Zhang, T. Bio-synthesis of Phytosterol Laurate in Non-aqueous Phase Reaction. Food Ferment. Ind. 2011, 37, 37-41. [CrossRef]

114. He, W.-S.; Li, L.; Zhao, J.; Xu, H.; Rui, J.; Cui, D.; Li, H.; Zhang, H.; Liu, X. Candida sp. 99-125 lipase-catalyzed synthesis of ergosterol linolenate and its characterization. Food Chem. 2019, 280, 286-293. [CrossRef]

115. Dong, Z.; Liu, Z.; Shi, J.; Tang, H.; Xiang, X.; Huang, F.; Zheng, M. Carbon Nanoparticle-Stabilized Pickering Emulsion as a Sustainable and High-Performance Interfacial Catalysis Platform for Enzymatic Esterification/Transesterification. ACS Sustain. Chem. Eng. 2019, 7, 7619-7629. [CrossRef]

116. Xiao, Y.; Zheng, M.; Liu, Z.; Shi, J.; Huang, F.; Luo, X. Constructing a Continuous Flow Bioreactor Based on a Hierarchically Porous Cellulose Monolith for Ultrafast and Nonstop Enzymatic Esterification/Transesterification. ACS Sustain. Chem. Eng. 2019, 7, 2056-2063. [CrossRef]

117. Zheng, M.; Zhu, J.; Huang, F.; Xiang, X.; Shi, J.; Deng, Q.; Ma, F.; Feng, Y. Enzymatic deacidification of the rice bran oil and simultaneous preparation of phytosterol esters-enriched functional oil catalyzed by immobilized lipase arrays. RSC Adv. 2015, 5, 70073-70079. [CrossRef]

118. Wang, X.; Xiao, B.; Yang, G.; Chen, J.; Liu, W. Enzymatic preparation of phytosterol esters with fatty acids from high-oleic sunflower seed oil using response surface methodology. RSC Adv. 2021, 11, 15204-15212. [CrossRef]

119. Li, P.; Liu, G.; Chen, J.; Li, L. Enzymatic synthesis of phytosterol esters with pyruvate and phytosterol. China Oils Fats 2012, 10. Available online: http://en.cnki.com.cn/Article_en/CJFDTotal-ZYZZ201210010.htm (accessed on 16 November 2021).

120. Tan, Z.; Le, K.; Moghadasian, M.; Shahidi, F. Enzymatic synthesis of phytosteryl docosahexaneates and evaluation of their anti-atherogenic effects in apo-E deficient mice. Food Chem. 2012, 134, 2097-2104. [CrossRef]

121. Wang, H.; Jia, C.; Xia, X.; Karangwa, E.; Zhang, X. Enzymatic synthesis of phytosteryl lipoate and its antioxidant properties. Food Chem. 2018, 240, 736-742. [CrossRef]

122. Schär, A.; Liphardt, S.; Nyström, L. Enzymatic synthesis of steryl hydroxycinnamates and their antioxidant activity. Eur. J. Lipid Sci. Technol. 2017, 119, 1600267. [CrossRef]

123. Yu, D.; Zhang, X.; Wang, T.; Geng, H.; Wang, L.; Jiang, L.; Elfalleh, W. Immobilized Candida antarctica lipase B (CALB) on functionalized MCM-41: Stability and catalysis of transesterification of soybean oil and phytosterol. Food Biosci. 2021, $40,100906$. [CrossRef]

124. Miao, M.; Liu, H.; Jiang, B.; Yang, C.; Xia, X.; Zhang, T. Enzyme-catalysed synthesis of plant steryl laurate in non-aqueous media using salt hydrate pairs and its characterisation. J. Funct. Foods 2014, 7, 452-461. [CrossRef]

125. Li, R.; Zhang, X.M. Lipase2catalyzed synthesis of $\beta$-sitosterol ester with conjugated linoleic acid in organic solvent. China Oils Fats 2006, 31. Available online: https:/ / en.cnki.com.cn/Article_en/CJFDTotal-ZYZZ200602018.htm (accessed on 28 November 2021).

126. Yang, T.; Zhang, Y.; Wang, J.; Huang, F.; Zheng, M. Magnetic Switchable Pickering Interfacial Biocatalysis: One-Pot Cascade Synthesis of Phytosterol Esters from High-Acid Value Oil. ACS Sustain. Chem. Eng. 2021, 9, 12070-12078. [CrossRef]

127. Rui, L.; Jia, C.S.; Lin, Y.; Zhang, X.M.; Xia, Q.Y.U.; Zhao, S.L.; Biao, F.; Fang, Z.A.; Chen, W.J. Lipase-Catalyzed Synthesis of Conjugated Linoleyl $\beta$-Sitosterol and Its Cholesterol-Lowering Properties in Mice. J. Agric. Food Chem. 2010, 58, 1898-1902. [CrossRef]

128. Luo, R.; Zeng, C.; Xu, D.; Chen, H. Lipase-catalyzed synthesis of phytosterol myristate. Sci. Technol. Food Ind. 2012, 9. Available online: https:/ / en.cnki.com.cn/Article_en/CJFDTotal-SPKJ201209036.htm (accessed on 28 November 2021).

129. Mao, Y.; Xu, D.; Yang, B.; Chen, H.; Zhao, J. Lipase-catalyzed synthesis of phytosterol palmitate esters in organic media. China Oils Fats 2011, 12. Available online: https:/ / en.cnki.com.cn/Article_en/CJFDTotal-ZYZZ201112008.htm (accessed on 28 November 2021).

130. Hu, L.; Llibin, S.; Li, J.; Qi, L.; Zhang, X.; Yu, D.; Walid, E.; Jiang, L. Lipase-catalyzed transesterification of soybean oil and phytosterol in supercritical $\mathrm{CO}_{2}$. Bioprocess Biosyst. Eng. 2015, 38, 2343-2347. [CrossRef] 
131. Liu, Z.; Sun, H.; Geng, C.; Han, Y. Optimization of Lipase catalyzed synthesis of conjugated linoleic acid phytosterol ester. J. Northwest A F Univ.-Nat. Sci. Ed. 2014, 42, 173-179.

132. Zhu, Z.; Xu, L.; Zhang, H.; Yan, Y. Optimization of Candida rugosa lipase catalyzed synthesis of sterol conjugated linoleic acid ester by response surface methodology. China Oils Fats 2013, 7. Available online: https://en.cnki.com.cn/Article_en/CJFDTotalZYZZ201307013.htm (accessed on 28 November 2021).

133. Li, J.; Deng, Q.; Zhang, P.; Huang, F. Research on synthesis process of phytosterols $\alpha$-linolenate by catalysis of lipase. Sci. Technol. Food Ind 2008, 12, 128-131.

134. Yu, D.; Yu, C.; Wang, T.; Chen, J.; Zhang, X.; Wang, L.; Qin, L.; Wu, F. Study on the Deacidification of Rice Bran Oil Esterification by Magnetic Immobilized Lipase. Catal. Lett. 2020, 150, 1256-1267. [CrossRef]

135. Zhou, H.; Jiang, Z.; Ren, L.; Yu, M.; Zhou, H.; Wei, P. Synthesis of Phytosterol Esters Catalyzed by Immobilized Lipase in Solvent-free System. Available online: https://en.cnki.com.cn/Article_en/CJFDTotal-HGYJ201603022.htm (accessed on 16 November 2021).

136. Sengupta, A.; Ghosh, M. The kinetics of enzyme catalyzed synthesis of sterol ester. Eur. J. Lipid Sci. Technol. 2011, 113, 763-767. [CrossRef]

137. Zheng, M.M.; Wang, L.; Huang, F.H.; Dong, L.; Guo, P.M.; Deng, Q.C.; Li, W.L.; Zheng, C. Ultrasonic pretreatment for lipasecatalyed synthesis of phytosterol esters with different acyl donors. Ultrason. Sonochem. 2012, 19, 1015-1020. [CrossRef] [PubMed]

138. Domínguez De María, P.; Sánchez-Montero, J.M.; Sinisterra, J.V.; Alcántara, A.R. Understanding Candida rugosa lipases: An overview. Biotechnol. Adv. 2006, 24, 180-196. [CrossRef]

139. Tan, Z.; Shahidi, F. Phytosteryl sinapates and vanillates: Chemoenzymatic synthesis and antioxidant capacity assessment. Food Chem. 2013, 138, 1438-1447. [CrossRef]

140. Huang, F.; Zheng, M.; Shi, W.; Xiang, X.; Shi, J.; Deng, Q.; Li, W.; Wan, C. Method for Preparing Functional Edible Oil Rich in Phytosterol Esters and Diglycerides. U.S. Patent 10,258,058, 16 April 2019.

141. Kim, I.-H.; Nodasom; Jo, J.-J. Preparation Method of Fatty Acid Phytosterol Ester Using Immobilized Lipase Derived from Candida Rugosa. Korean Patent KR20150046397A, 30 April 2015.

142. Lillan, J.T.; Borch, S.J. Method for Producing Phytosterol/Phytostanol Phospholipid Esters. U.S. Patent 13/231,355, 7 June 2012.

143. Hu, X.; Chen, H.; Jiang, M.; Dong, X.; Liu, C.; Wei, F.; Zhang, Y.; Huang, F. Method for Producing Plant Sterol Ester by Immobilized Whole-Cell Enzyme Catalysis in Solvent-Free System. CN Patent CN101200754B, 2 June 2010.

144. Zhang, Z.; Fan, L.-P.; Wang, Y.-J. Applications of Chemical Kinetics in Heterogeneous Catalysis. In Advanced Oxidation ProcessesApplications, Trends, and Prospects; IntechOpen: London, UK, 2020. [CrossRef]

145. Yahya, A.R.M.; Anderson, W.A.; Moo-Young, M. Ester synthesis in lipase-catalyzed reactions. Enzyme Microb. Technol. 1998, 23, 438-450. [CrossRef]

146. Handayani, S.; Tamara Putri, A.T.; Setiasih, S.; Hudiyono, S. Enzymatic Synthesis of Glyserol-Coconut Oil Fatty Acid and Glycerol-Decanoic Acis Ester as Emulsifier and Antimicrobial Agents Using Candida rugosa Lipase EC 3.1.1.3. In Conference Proceeding of The 3rd Asia-Pacific Conference on Life Science and Engineering (APCLSE); IOP Publishing: Bristol, UK, 2018; Volume 299, p. 12019. [CrossRef]

147. Senoymak Tarakc1, M.I.; Ilgen, O. Esterification of Oleic Acid with Methanol Using $\mathrm{Zr}\left(\mathrm{SO}_{4}\right)_{2}$ as a Heterogeneous Catalyst. Chem. Eng. Technol. 2018, 41, 845-852. [CrossRef]

148. Hernáiz, M.J.; Sánchez-Montero, J.M.; Sinisterra, J.V. New differences between isoenzymes A and B from Candida rugosa lipase. Biotechnol. Lett. 1997, 19, 303-306. [CrossRef]

149. Molina-Gutiérrez, M.; Hakalin, N.L.S.; Rodríguez-Sanchez, L.; Prieto, A.; Martínez, M.J. Green synthesis of $\beta$-sitostanol esters catalyzed by the versatile lipase/sterol esterase from Ophiostoma piceae. Food Chem. 2017, 221, 1458-1465. [CrossRef]

150. Khan, N.R.; Rathod, V.K. Enzyme catalyzed synthesis of cosmetic esters and its intensification: A review. Process Biochem. 2015, 50, 1793-1806. [CrossRef]

151. Ben Akacha, N.; Gargouri, M. Microbial and enzymatic technologies used for the production of natural aroma compounds: Synthesis, recovery modeling, and bioprocesses. Food Bioprod. Process. 2015, 94, 675-706. [CrossRef]

152. Patel, V.; Gajera, H.; Gupta, A.; Manocha, L.; Madamwar, D. Synthesis of ethyl caprylate in organic media using Candida rugosa lipase immobilized on exfoliated graphene oxide: Process parameters and reusability studies. Biochem. Eng. J. 2015, 95, 62-70. [CrossRef]

153. Klibanov, A.M. Asymmetric Transformations Catalyzed by Enzymes in Organic Solvents. Acc. Chem. Res. 1990, 23, 114-120. [CrossRef]

154. Castro-Ochoa, L.D.; Rodríguez-Gómez, C.; Valerio-Alfaro, G.; Oliart Ros, R. Screening, purification and characterization of the thermoalkalophilic lipase produced by Bacillus thermoleovorans CCR11. Enzyme Microb. Technol. 2005, 37, 648-654. [CrossRef]

155. Kumar, A.; Dhar, K.; Kanwar, S.S.; Arora, P.K. Lipase catalysis in organic solvents: Advantages and applications. Biol. Proced. Online 2016, 18, 2. [CrossRef]

156. Khmelnitsky, Y.L.; Levashov, A.V.; Klyachko, N.L.; Martinek, K. Engineering biocatalytic systems in organic media with low water content. Enzyme Microb. Technol. 1988, 10, 710-724. [CrossRef]

157. Duan, Z.Q.; Du, W.; Liu, D.H. The mechanism of solvent effect on the positional selectivity of Candida antarctica lipase B during 1,3-diolein synthesis by esterification. Bioresour. Technol. 2011, 102, 11048-11050. [CrossRef] [PubMed] 
158. Torres, C.F.; Fornari, T.; Torrelo, G.; Señoráns, F.J.; Reglero, G. Production of phytosterol esters from soybean oil deodorizer distillates. Eur. J. Lipid Sci. Technol. 2009, 111, 459-463. [CrossRef]

159. Stergiou, P.Y.; Foukis, A.; Filippou, M.; Koukouritaki, M.; Parapouli, M.; Theodorou, L.G.; Hatziloukas, E.; Afendra, A.; Pandey, A.; Papamichael, E.M. Advances in lipase-catalyzed esterification reactions. Biotechnol. Adv. 2013, 31, 1846-1859. [CrossRef] [PubMed]

160. Villeneuve, P. Lipases in lipophilization reactions. Biotechnol. Adv. 2007, 25, 515-536. [CrossRef] [PubMed]

161. Napier, P.E.; Lacerda, H.M.; Rosell, C.M.; Valivety, R.H.; Vaidya, A.M.; Halling, P.J. Enhanced organic-phase enzymatic esterification with continuous water removal in a controlled air-bleed evacuated-headspace reactor. Biotechnol. Prog. 1996, 12, 47-50. [CrossRef]

162. Meissner, J.P.; Carta, G. Continuous Regioselective Enzymatic Esterification in a Simulated Moving Bed Reactor. Ind. Eng. Chem. Res. 2002, 41, 4722-4732. [CrossRef]

163. Gubicza, L.; Nemestóthy, N.; Fráter, T.; Bélafi-Bakó, K. Enzymatic esterification in ionic liquids integrated with pervaporation for water removal. Green Chem. 2003, 5, 236-239. [CrossRef]

164. Bloomer, S.; Adlercreutz, P.; Mattiasson, B. Facile synthesis of fatty acid esters in high yields. Enzyme Microb. Technol. 1992, 14, 546-552. [CrossRef]

165. Jeong, J.C.; Lee, S.B. Enzymatic esterification reaction in organic media with continuous water stripping: Effect of water content on reactor performance and enzyme agglomeration. Biotechnol. Technol. 1997, 11, 853-858. [CrossRef]

166. Won, K.; Lee, S.B. Online conversion estimation for solvent-free enzymatic esterification systems with water activity control. Biotechnol. Bioprocess Eng. 2002, 7, 76-84. [CrossRef]

167. Won, K.; Lee, S.B. Computer-aided control of water activity for lipase-catalyzed esterification in solvent-free systems. Biotechnol. Prog. 2001, 17, 258-264. [CrossRef]

168. Petersson, A.E.V.; Adlercreutz, P.; Mattiasson, B. A water activity control system for enzymatic reactions in organic media. Biotechnol. Bioeng. 2007, 97, 235-241. [CrossRef]

169. Shirsath, S.R.; Sonawane, S.H.; Gogate, P.R. Intensification of extraction of natural products using ultrasonic irradiations-A review of current status. Chem. Eng. Process. Process Intensif. 2012, 53, 10-23. [CrossRef]

170. Bansode, S.R.; Rathod, V.K. Ultrasound assisted lipase catalysed synthesis of isoamyl butyrate. Process Biochem. 2014, 49 , 1297-1303. [CrossRef]

171. Chen, H.C.; Chen, J.H.; Chang, C.; Shieh, C.J. Optimization of ultrasound-accelerated synthesis of enzymatic caffeic acid phenethyl ester by response surface methodology. Ultrason. Sonochem. 2011, 18, 455-459. [CrossRef]

172. Réjasse, B.; Lamare, S.; Legoy, M.D.; Besson, T. Stability improvement of immobilized Candida antarctica lipase B in an organic medium under microwave radiation. Org. Biomol. Chem. 2004, 2, 1086-1089. [CrossRef] [PubMed]

173. dos Santos, P.; Zabot, G.L.; Meireles, M.A.A.; Mazutti, M.A.; Martínez, J. Synthesis of eugenyl acetate by enzymatic reactions in supercritical carbon dioxide. Biochem. Eng. J. 2016, 114, 1-9. [CrossRef]

174. Nyström, L. Analysis Methods of Phytosterols. Anal. Antioxid.-Rich Phytochem. 2012, 313-351. [CrossRef]

175. Piironen, V.; Lampi, A.-M. Occurrence and Levels of Phytosterols in Foods. In Phytosterols as Functional Food Components and Nutraceuticals; Dutta, P.C., Ed.; Marcel Dekker: New York, NY, USA, 2003.

176. Abe, H.; Soeno, K.; Koseki, N.N.; Natsume, M. Conjugated and unconjugated brassinosteroids. In ACS Symposium Series; ACS: Washington, DC, USA, 2001; Volume 774, pp. 91-101. [CrossRef]

177. Carretero, A.S.; Carrasco-Pancorbo, A.; Cortacero, S.; Gori, A.; Cerretani, L.; Fernández-Gutiérrez, A. A simplified method for HPLC-MS analysis of sterols in vegetable oil. Eur. J. Lipid Sci. Technol. 2008, 110, 1142-1149. [CrossRef]

178. Breinhölder, P.; Mosca, L.; Lindner, W. Concept of sequential analysis of free and conjugated phytosterols in different plant matrices. J. Chromatogr. B Anal. Technol. Biomed. Life Sci. 2002, 777, 67-82. [CrossRef]

179. Sun, Y.; Deng, Z.; Liu, R.; Zhang, H.; Zhu, H.; Jiang, L.; Tsao, R. A comprehensive profiling of free, conjugated and bound phenolics and lipophilic antioxidants in red and green lentil processing by-products. Food Chem. 2020, 325, 126925. [CrossRef]

180. Junker, J.; Chong, I.; Kamp, F.; Steiner, H.; Giera, M.; Müller, C.; Bracher, F. Comparison of strategies for the determination of sterol sulfates via GC-MS leading to a novel deconjugation-derivatization protocol. Molecules 2019, 24, 2353. [CrossRef]

181. Smith, D.; McEwan, M.J.; Španěl, P. Understanding Gas Phase Ion Chemistry Is the Key to Reliable Selected Ion Flow Tube-Mass Spectrometry Analyses. Anal. Chem. 2020, 92, 12750-12762. [CrossRef]

182. Ishida, N. A method for simultaneous analysis of phytosterols and phytosterol esters in tobacco leaves using non aqueous reversed phase chromatography and atmospheric pressure chemical ionization mass spectrometry detector. J. Chromatogr. A 2014, 1340, 99-108. [CrossRef]

183. Zhang, J.; Zhang, T.; Tao, G.; Liu, R.; Chang, M.; Jin, Q.; Wang, X. Characterization and determination of free phytosterols and phytosterol conjugates: The potential phytochemicals to classify different rice bran oil and rice bran. Food Chem. 2021, 344,128624 [CrossRef]

184. Nzekoue, F.K.; Caprioli, G.; Ricciutelli, M.; Cortese, M.; Alesi, A.; Vittori, S.; Sagratini, G. Development of an innovative phytosterol derivatization method to improve the HPLC-DAD analysis and the ESI-MS detection of plant sterols/stanols. Food Res. Int. 2020, 131, 108998. [CrossRef]

185. de Sousa, R.R.; da Silva, A.S.; Fernandez-Lafuente, R.; Ferreira-Leitão, V.S. Simplified method to optimize enzymatic esters syntheses in solvent-free systems: Validation using literature and experimental data. Catalysts 2021, 11, 1357. [CrossRef] 